\title{
The HIV Epidemic: High-Income Countries
}

\author{
Sten H. Vermund ${ }^{1}$ and Andrew J. Leigh-Brown ${ }^{2}$ \\ ${ }^{1}$ Institute for Global Health and Department of Pediatrics, Vanderbilt University School of Medicine, \\ Nashville, Tennessee 37203 \\ ${ }^{2}$ Institute of Evolutionary Biology, University of Edinburgh, Edinburgh, Scotland EH9 3JT, United Kingdom \\ Correspondence: sten.vermund@vanderbilt.edu
}

\begin{abstract}
The HIV epidemic in higher-income nations is driven by receptive anal intercourse, injection drug use through needle/syringe sharing, and, less efficiently, vaginal intercourse. Alcohol and noninjecting drug use increase sexual HIV vulnerability. Appropriate diagnostic screening has nearly eliminated blood/blood product-related transmissions and, with antiretroviral therapy, has reduced mother-to-child transmission radically. Affected subgroups have changed over time (e.g., increasing numbers of Black and minority ethnic men who have sex with men). Molecular phylogenetic approaches have established historical links between HIV strains from central Africa to those in the United States and thence to Europe. However, Europe did not just receive virus from the United States, as it was also imported from Africa directly. Initial introductions led to epidemics in different risk groups in Western Europe distinguished by viral clades/sequences, and likewise, more recent explosive epidemics linked to injection drug use in Eastern Europe are associated with specific strains. Recent developments in phylodynamic approaches have made it possible to obtain estimates of sequence evolution rates and network parameters for epidemics.
\end{abstract}

$T_{\text {hesion }}$ he social and molecular epidemiology of the HIV epidemic in higher-income countries has had characteristics quite distinct from the situation in the most highly affected regions of sub-Saharan Africa (Kilmarx 2009). Since the recognition of AIDS in 1981, high-income nations have had their own characteristic epidemic trends, transmission dynamics, affected subgroups, and recent trends. We focus on the higher-income nations of Western Europe, North America, and many nations of Oceania, including Australia and New Zealand. We acknowledge that one must also consider the proximity of Eastern Europe, Caribbean, and the rest of Oceania, acknowledging that most of them are high- or low- middle-income nations, not high income; neither are they as resourcelimited as those reviewed by Williamson and Shao 2011 (Haiti and a few others are exceptions). We seek to summarize a complex matrix of biological phenomena in a complex disease that is steeped in human behavior and stigma, fear, and prejudice (Remien and Mellins 2007; Mahajan et al. 2008).

HIV / AIDS shares transmission characteristics with other sexual and blood-borne agents. Higher sexual mixing rates and lack of condom use are conspicuous risk factors (Vermund et al. 2009). Reuse of syringes and needles, receipt of contaminated blood or blood products, or

Editors: Frederic D. Bushman, Gary J. Nabel, and Ronald Swanstrom

Additional Perspectives on HIV available at www.perspectivesinmedicine.org

Copyright (C) 2012 Cold Spring Harbor Laboratory Press; all rights reserved; doi: 10.1101/cshperspect.a007195

Cite this article as Cold Spring Harb Perspect Med 2012;2:a007195 
occupational needle sticks in a health care setting all are associated with HIV infection. Mother-to-child transmission prepartum, intrapartum, or postpartum via breast milk feeding is an additional major transmission route (Fowler et al. 2010). Since the advent of antiretroviral therapy and routine screening of women in pregnancy, the number of infants infected with HIV in high-income nations has plummeted, although cases still occur (Birkhead et al. 2010; Lampe et al. 2010; Whitmore et al. 2010, 2011).

HIV is the most dangerous of the sexual and blood-borne diseases in its epidemic potential and its virulence. Our inability to cure HIV infection adds to the complexity of its chronic management. In addition, HIV seems to be spread more like hepatitis B virus (HBV) than any other infectious agent (sex, blood, or perinatal), although it is not as infectious as HBV (Barth et al. 2010; Dwyre et al. 2011). Classical sexually transmitted diseases (SDIs) are rarely blood-borne, although sexual and perinatal HIV transmission occurs as with HBV, herpes simplex type 2 (HSV-2), syphilis, gonorrhea, and chlamydia. Hepatitis $\mathrm{C}$ virus (HCV) is transmitted overwhelmingly through bloodborne routes, with sexual and perinatal cases occurring rarely. Human T-lymphotropic virus type 1 (HTLV-1) is transmitted most often via breast milk; HTLV-2 transmission has been reported via needle exchange. Although HIV is surely reminiscent of other infectious agents, its unique $\mathrm{CD}^{+}{ }^{+}$T-lymphocyte tropism helps dictate its exact transmission routes and frequencies (see Shaw and Hunter 2011).

Sadly, the early history of the HIV epidemic is one of missed opportunities, over and over, in country after country. This continues to the present day (Mahy et al. 2009). The failure to see the now-obvious parallels in risk with HBV led to a failure to protect the blood supply in the early 1980s during an intense transmission period, resulting in the preventable infection of thousands of blood recipients, particularly men with hemophilia. The failure to aggressively advocate sexual risk reduction, including delayed coital debut among adolescents, reduced numbers of sexual partners, and use of condoms, led to unknown numbers of same sex and heterosexual HIV transmissions. Even in 2011, members of the U.S. Congress demonize such organizations as Planned Parenthood that advocate pregnancy and HIV/STD prevention, empowering the poor and the young to access their unmet needs for these services. The failure to promptly, consistently, and extensively provide clean needles and syringes for IDUs (and for health care in resource-limited settings) led to an estimated 4394 to 9666 preventable infections in the U.S. alone $(33 \%$ of the incidence in IDUs) from 1987 to 1995 , costing society US\$244 to US\$538 million (Lurie and Drucker 1997). The U.S. Federal Government did not lift its ban on funding for needle/syringe exchange programs (N/SEP) until 2009, despite overwhelming evidence indicating its effectiveness in preventing HIV transmission. Although beyond the scope of this work, the failure of many high-income nations to liberate public health professionals and community activists to address the problem using evidence-based solutions, rather than using HIV/AIDS as a politicized point of ideological conflict, costs, and continues to cost, lives (Mathers et al. 2010).

Here we present the characteristics of viral evolution as seen in high-income nations, primarily in the northern hemisphere, including issues of viral diversity and transmission. We further present a brief review of major risk exposures for HIV and their importance in the epidemic patterns of higher-income nations.

\section{OVERVIEW OF VIRUS EVOLUTION AND RATES OF CHANGE}

The rapidity of HIV evolution is such a prominent feature of the virus that it has attracted extensive attention since the development of thermostable polymerases allowed it to be easily studied (Meyerhans et al. 1989; Balfe et al. 1990; Wolfs et al. 1990). This required a revolution in the thinking of virologists, many of whom had previously been familiar with the evolution of DNA viruses, which diverge slowly and often 
in parallel with their hosts (Sambrook et al. 1980). ${ }^{3}$ These differences gradually became apparent more widely, and both the data and methodology developed (Crandall et al. 1999) to reveal the conflicting forces that act on the HIV population to force the highest rates of amino acid substitution known (under selection by drugs, cytotoxic T-lymphocytes [CTLs], or by neutralizing antibody) (Frost et al. 2000, 2005) (see Carrington and Alter 2011; Lackner et al. 2011; Overbaugh and Morris 2011; Swanstrom and Coffin 2011; Walker and McMichael 2011) and yet allow chance effects to play a significant role in viral evolution (Leigh Brown 1997; Leigh Brown and Richman 1997). The impact on HIV evolution of the complexity of the processes and forces involved, and their interactions, have been reviewed effectively elsewhere (Rambaut et al. 2004), so only recent developments will be looked at further here.

Powerful, statistically rigorous techniques for estimation of molecular evolutionary parameters are now available and have been applied to HIV sequences from infected populations to estimate both the rate of evolutionary change and dates of divergence (Drummond and Rambaut 2007). These studies, however, have a long history: Estimates of the rate of synonymous nucleotide substitution made 20 years ago (Balfe et al. 1990; Wolfs et al. 1990) of the order of $5 \times 10^{-3}$ were not very different from those made recently $\left(2-6 \times 10^{-3}\right)$ (Korber et al. 2000; Robbins et al. 2003; Lewis et al. 2008). What has changed is that such estimates can now be made on large and complex data sets instead of being restricted to relatively uniform well-defined outbreaks. The first demonstration of the power of the new approaches was the timing of the origin of the pandemic HIV "M" strain to the early 20th century (Korber et al. 2000) (see also Sharp and Hahn 2011). More recently they have allowed estimates to be made of the origins of diverse epidemics in

${ }^{3}$ Summarized succinctly by one of the leading figures in the molecular characterization of HIV in the 1980s, Simon Wain-Hobson: "The problem of HIV evolution ... is one of population genetics" (in conversation with ALB at the Institut Pasteur, August 1988). different countries and risk groups (Lemey et al. 2003; Salemi et al. 2008). Finally, in combination with very large data sets, these approaches have allowed a bridge to be made across to infectious disease epidemiology, as under certain assumptions, the viral evolutionary history can be used to estimate critical epidemiological parameters that are not accessible from other routes (Volz et al. 2009).

\section{Major Clades}

Across the globe, comparisons between viruses isolated in the 1980s from different populations of HIV-infected individuals frequently showed much greater differences than were seen within populations. These became termed "subtypes," although, as there is no clear serological distinction, the generic term "clade" is more appropriate. National epidemics were initially only associated with one clade, with the exception of Thailand, where two major forms were recognized early on. The distinction between "Thai A" (now called CRF01) and "Thai B" strains (Ou et al. 1993) gave rise to the name of the HIV clade that had spread across the United States and Western Europe in the 1980s: "subtype B.” Likewise, East Africa was another locus where two subtypes became established and cocirculated: the "A" and "D" clades (see Sharp and Hahn 2011; Williamson and Shao 2011). In addition, owing to the recombinogenic nature of HIV replication, recombinants between these clades arise wherever cocirculation occurs, and several have given rise to epidemics themselves; these have become termed circulating recombinant forms, or "CRFs" (Robertson et al. 2000), whose names identify the parent strains. Classification systems are frequently superseded by later knowledge, and this is no exception, as the best known "recombinant," the Thai "A" strain or CRF01/AE, evidence for whose hypothesized second parent "E" has always been lacking, now appears rather to be a divergent form of subtype A (Anderson et al. 2000). Similarly, it appears that CRF02/AG is a parental, rather than recombinant form (Abecasis et al. 2007). In recent years the genetic complexity of the global epidemic has increased 
substantially, with more than 40 CRFs now recognized (Kuiken et al. 2010), instead of the original four (Robertson et al. 2000).

Genetic diversity of HIV has always been greatest in west central Africa. Here all major clades (A-K, with the exception of the "B" and missing " $\mathrm{E}$ " clades) have been found, and indeed, especially among strains from the 1980s, many intermediate and unclassifiable forms (Kalish et al. 2004), as expected for the region where the pandemic originated (Rambaut et al. 2001; see Sharp and Hahn 2011). The lack of major biological differences among HIV clades has led to the view that their distinctiveness has arisen primarily through the stochastic process of founder events, via the chance appearance of virus from a particular origin in a highly susceptible population (Rambaut et al. 2004). Dating the divergence events using molecular clock-based approaches suggests the divergence of the major clades, which took place here, occurred around the middle of the 20th century (Korber et al. 2000), but seeding of the northern hemisphere has often been from other parts of Africa, and after distinct clades emerged.

\section{Virus Diversity in the Northern Hemisphere}

\section{North America}

Given what is known of the pathogenesis of HIV disease, the origin of HIV infection in the northern hemisphere had to have predated the original description of AIDS in 1981 by several years. Indeed, serosurveillance studies showed that the prevalence of HIV infection among men who have sex with men (MSM), which was $20 \%-40 \%$ by the early 1980 s, was already between $4 \%$ and $7 \%$ in San Francisco, New York, and Los Angeles in the late 1970s (Coutinho et al. 1989). Nevertheless, analysis of nucleotide sequences from strains isolated in the 1980s (Robbins et al. 2003) confirmed the earlier estimate (Korber et al. 2000), that the common ancestor of the HIV strains found in the United States preceded that period by approximately 10 years. The final piece in this puzzle was found when a number of sequences of HIV from Haitian immigrants to the United States who were HIV-infected in the 1980s were compared to United States sequences (Gilbert et al. 2007). These belonged to the same (B) clade but all branched off earlier. Using similar dating approaches, the origin of the U.S. clade is confirmed at 1969, whereas the common ancestor of the Haitian strains predated this by a few years at 1966 (Gilbert et al. 2007). This is the closest that can currently be reached to the reconstruction of the origin of the northern hemisphere epidemic and the B subtype. The $B$ subtype was not found among early sequences from Africa (it was introduced later to South African MSM); the most closely related sequences from Africa are from the D clade, within which, when early African sequences are included, the B clade nests (Kalish et al. 2004). The date for this B-D divergence is around 1954 (Gilbert et al. 2007), consistent with the placing of a sequence fragment from a sample from Kinshasa in 1957 very near the split, but in the D clade (Korber et al. 2000). It has been speculated that the return in the 1960s of expatriate Haitians from the diaspora of the 1950s to Francophone West Africa was responsible. It is known that AIDS was recognized in Haiti much earlier than anywhere else, outside the three U.S. cities (Los Angeles, New York, and San Francisco), and that initially the infection was predominantly in men, only becoming a generalized epidemic over the next decade (Pape and Johnson 1993).

The reconstruction, through molecular phylogenetics, of the connections which linked a then obscure syndrome among a number of homosexual men in U.S. cities to central Africa, where the infection had not at the time been recognized, is the most striking of many examples where sequencing of viral strains has yielded important information for epidemiology. The pattern of introduction in Europe, however, was more complex.

\section{Europe 1980-1990}

Identification of AIDS in Europe followed its recognition in the United States. Once recognized, retrospective investigation identified a 
The HIV Epidemic: High-Income Countries

few cases that could be traced back to the 1970s, but among MSM many of the earliest cases had direct recent links to the United States (Pinching 1984), and all MSM at that time were infected with a virus later characterized as the $\mathrm{B}$ clade. These introductions of the virus probably continued: It has been estimated by reconstructing viral lineages among MSM in the United Kingdom that at least six lineages are represented in present day populations, most, but not all, of which had an origin in the early 1980s (Hue et al. 2005). These were already distinct $B$ clade lineages which represented independent introductions into the United Kingdom. Another introduction that appeared to be independent was into the injecting drug user population of northern Europe (Lukashov et al. 1996), among whom the virus was remarkably similar, whether in Amsterdam, Dublin, or Edinburgh, reflecting another founder introduction to a highly susceptible population (Leigh Brown et al. 1997; Op de Coul et al. 2001). The distinctiveness of this strain from that in MSM (Kuiken and Goudsmit 1994; Holmes et al. 1995; Kuiken et al. 1996) contrasted with that of hemophiliacs in Edinburgh, infected from locally prepared factor VIII in the early 1980s, whose virus could be linked directly to that found in Scottish MSM (Brown et al. 1997). Interestingly, the distinction is less apparent in IDUs from southern Europe from this period, whose sequences overlapped more with those from MSM (Lukashov et al. 1996). The epidemics also behaved differently in these two areas, stabilizing in the north while leading to the highest prevalence in Europe in Spain, Italy, and Portugal (Hamers et al. 1997).

Europe did not just receive virus from the United States, however; it was also imported from Africa directly (Fig. 1). Molecular epidemiological evidence suggests strongly that since the 1960s, HIV-1 and HIV-2 have been transported from Africa to North America/Caribbean and Europe, and have been transported, too, between the European and North American continents (Fig. 1). Cases were recognized almost as early among individuals having links to Africa (Alizon et al. 1986), and these led to local epidemics of non-B clades. One hospital in Paris recorded eight clades, including CRF01AE by 1995 (Simon et al. 1996), but although several clades were recorded in the United Kingdom, in relative terms, the prevalence of

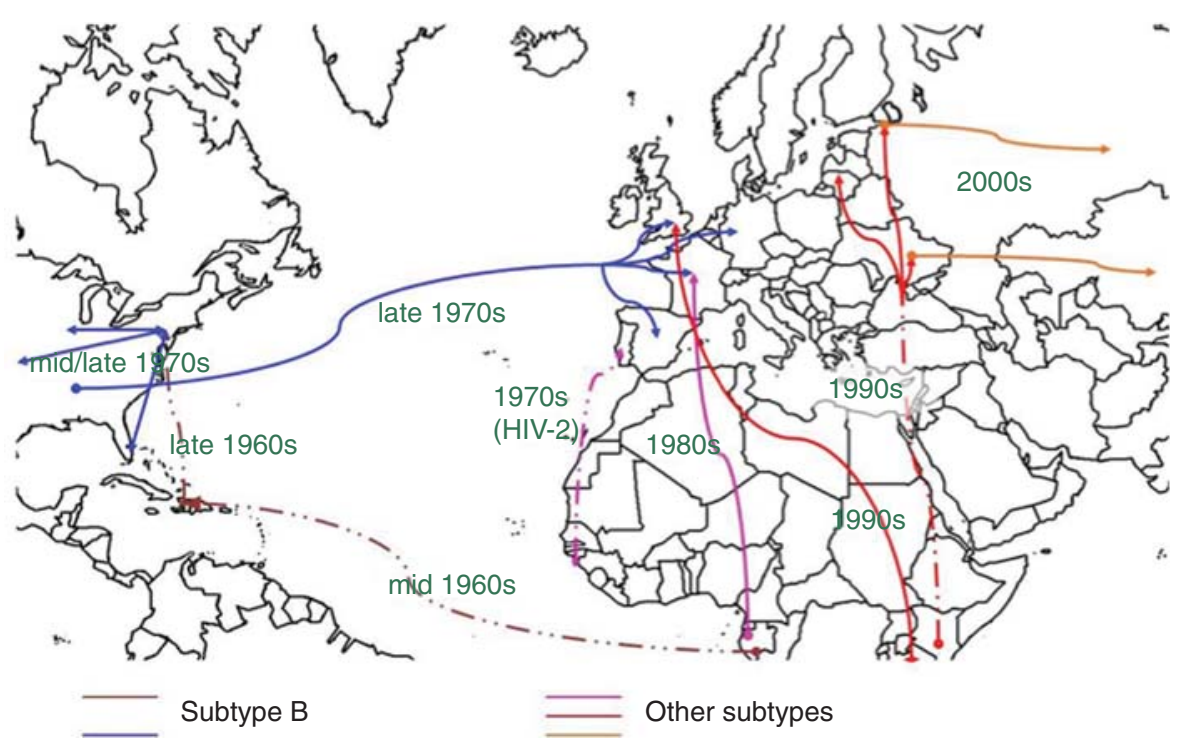

Figure 1. Dates of likely introductions of HIV to various parts of the world since the 1960s. 
S.H. Vermund and A.J. Leigh-Brown

non-B strains at that time was low (Arnold et al. 1995). Patterns of strain prevalence reflected past colonial links and frequency of contemporary interchange, strikingly so in the case of Portugal, the only country outside West Africa to record a significant epidemic of HIV-2 (De Cock and Brun-Vezinet 1989), reflecting the location of its former colony Guinea-Bissau at the epicenter of the HIV-2 epidemic. The molecular distinctions between European epidemics extended to the HIV-1 clades, however, with clade $\mathrm{G}$, associated with West Africa, being well represented in Portugal but not elsewhere in Western Europe. However, it gave rise to an iatrogenic outbreak in southern Russia in 1988 (in Elista, $300 \mathrm{~km}$ south of Volgograd) (Bobkov et al. 1994), and the devastating iatrogenic outbreak in Romanian children (Hersh et al. 1991b) was associated with clade F (Thomson et al. 2002).

\section{Europe 1990-2005}

Those initial introductions into Western Europe led to epidemics in different risk groups in different regions often distinguished by viral clade, thus in France, transmission among IDUs and MSM remained of the B subtype, whereas heterosexual transmission was more commonly of a variety of non-B subtypes, as was the case in Switzerland (Op de Coul et al. 2001). Non-B subtypes were present but rare in the UK until 1995, after which a substantial increase in immigration from southern Africa, particularly Zimbabwe, led to a dramatic rise in subtypes $\mathrm{C}$ and A (Parry et al. 2001). By 2005, the prevalence of non-B clades taken together equaled the B clade, and recently, in both France and the United Kingdom, there has been noticeable, and nonreciprocal, crossover of non-B clades into MSM (de Oliveira et al. 2010; Fox et al. 2010). Similarly, Swiss investigators have confirmed changes in B clade viral transmission over time (Kouyos RD et al. 2010).

The breakup of the Soviet Union and the Eastern European bloc at the end of the 1980s, the subsequent economic decline in some of these countries, and the freeing of travel in the 1990s was a combination that had devastating consequences regarding HIV transmission. A very large population of injection drug users adopting highly unsafe practices (Dehne et al. 1999) was the focus of massive, explosive epidemics (Aceijas et al. 2004). Virus obtained in 1995 from Donetsk in eastern Ukraine and Krasnodar in southern Russia, about $350 \mathrm{~km}$ distant, were very similar, with about $2 \%$ divergence in the $\mathrm{C} 2-\mathrm{V} 3$ region, and belonged to subtype A but had some unique features (Bobkov et al. 1997) that allowed it to be easily tracked as it spread from Ukraine to St. Petersburg and Estonia in the 1990s and then in the 21st century, on to other parts of Russia, including Moscow and Irkutsk (Siberia) (Bobkov et al. 2001), as well as neighbors, including Kazakhstan (Bobkov et al. 2004) and the Baltic states (Zetterberg et al. 2004). Soon after the original outbreak in Ukraine, there was an explosive outbreak in the Former Soviet Union enclave of Kaliningrad. This was characterized by a quite distinct $\mathrm{A} / \mathrm{B}$ recombinant (Liitsola et al. 1998), which detailed analysis suggests was derived from subtype B and A variants found among IDUs in Ukraine (Liitsola et al. 2000).

\section{DRUG-RESISTANT HIV AND ITS TRANSMISSION}

From very early days of antiretroviral therapy, the transmission of drug-resistant virus was already being recorded. Clear evidence was presented in three different countries that before 1995, mutations at amino acid 215 in reverse transcriptase were present in untreated individuals (Perrin et al. 1994; de Ronde et al. 1996; Quigg et al. 1997). Systematic surveys of the presence of such mutations have followed, initially linked to studies of acute infection (Little et al. 1999, 2002). Later studies extended this to include individuals in chronic infection, which could be studied in larger numbers (Weinstock et al. 2004; Cane et al. 2005; Wensing et al. 2005; Chaix et al. 2009; Vercauteren et al. 2009). The overall picture appears to indicate an increase in transmission of drug resistance in the late 1990s as more individuals went on therapy (Leigh Brown et al. 2003), which was followed by a decrease, as more individuals on therapy 
became completely suppressed, but the exact timing was difficult to determine from chronic infection studies and may have varied between countries. In addition, there were differences in the classes of drug that were most strongly affected, with nonnucleoside resistance consistently appearing at a higher frequency than nucleoside or protease inhibitor resistance, reflecting differences in transmission fitness of nucleoside reverse transcriptase inhibitor (NNRTI) resistance-associated mutations (Leigh Brown et al. 2003). Most countries in the developed world have developed systematic surveillance for transmitted resistance to minimize its impact on individualized antiretroviral therapy.

\section{HIV Transmission Networks and Dynamics Revealed by Molecular Epidemiology}

Analyses of nucleotide sequence variation have been used for almost 20 years to describe the relationships between viral strains within infected communities (Balfe et al. 1990; Kuiken and Goudsmit 1994; Leigh Brown et al. 1997). Recently a combination of greatly enhanced data sets and improvements in methodology have allowed much more detail to be added to the depictions of the structure of the transmission networks deduced from sequence data. This has shown that some risk groups (e.g., injection drug users) can give rise to tight clusters where many individuals may share very similar sequences (Brenner et al. 2008; Yerly et al. 2009). In addition, for the first time it has become possible to investigate the dynamics of the epidemic based on such data. Although many studies of sexual behavior have shown that individuals can vary greatly in their number of sexual partners over time and this concept has underpinned many epidemiological models of HIV transmission, however, contact tracing has been shown to be poor at recovering the HIV transmission network relative to other infections (Yirrell et al. 1998; Resik et al. 2007). The development of the field of molecular phylodynamics, used first to estimate dates of the origin of the zoonotic transmission of
HIV, provided new routes to obtain such parameter estimates, which can be applied to small-scale intensive studies of specific outbreaks, as well as to obtain global estimates relating to long-term spread.

By analyzing the transmission network revealed by partial pol gene sequences obtained during routine clinical care, it was shown that the cluster size distribution of MSM attending a single large clinic in London had a long right tail, implying many individuals were associated with large clusters: In fact, of individuals in clusters $>2,25 \%$ were found in clusters $\geq 10$ (Lewis et al. 2008). Within these clusters, 25\% of intervals between transmissions, inferred from the dated transmission network, were 6 months or less, implying a significant role for acute infection in driving the epidemic (Cohen et al. 2011).

Extending this work to non-B subtypes, primarily associated with heterosexual infection in the United Kingdom, revealed that although clustering could be detected, it was much less extensive than among MSM, and the mean intertransmission interval was substantially longer. In fact, there were hardly any intervals $\leq 6 \mathrm{mo}$, indicating important differences between the epidemics in the two risk groups (Hughes et al. 2009).

\section{Example of Phylodynamic Modeling from the United Kingdom}

The phylodynamic approach has been extended to a population survey of viral sequences from the entire U.K. HIV epidemic among MSM (Leigh Brown et al. 2011). Partial pol gene sequences from approximately two-thirds of the MSM under care in the United Kingdom in 2007 have been analyzed. Of those linked to any other, $29 \%$ were linked to only 1, $41 \%$ linked to $2-10$, and $29 \%$ linked to $\geq 10$. In striking contrast, a recent update on transmission of non-B subtypes in the United Kingdom has revealed that only one large cluster is attributable to heterosexual transmission, all others being "crossovers" to IDU or MSM (S Hue et al., unpubl.). It has thus been possible to obtain estimates of network parameters for 
the entire epidemic in the United Kingdom. The scale of sequence data coverage greatly exceeds that generally achievable in epidemiological surveys of sexual contact. This provides an opportunity to make critical inferences on the impact of clustering for the epidemic, and its importance for intervention strategies. It is well understood that under certain conditions there is no "epidemic threshold," such that a randomly distributed (i.e., untargeted) intervention, will be unable to stop the epidemic (Keeling and Eames 2005). The estimates of epidemiological parameters based on data from routinely performed HIV genotyping tests therefore provide critical information for the successful and efficient implementation of transmission interventions including vaccination (when available), and for both antiretroviral treatment for prevention among infectous seropositives and preexposure prophylaxis among seronegatives (Burns et al. 2010; Kurth et al. 2011).

\section{RISK EXPOSURES: MSM}

The AIDS epidemic was recognized first among MSM in Los Angeles, New York, and San Francisco. Clinicians were alarmed to see gay men who presented with low $\mathrm{CD} 4^{+} \mathrm{T}$ lymphocytes and opportunistic infections like Pneumocystis jirovecii (P. carinii is the form seen in animals, now distinguished from the former human form) or malignancies like Kaposi's sarcoma (KS) (Centers for Disease Control 1981; Gottlieb et al. 1981). P. jirovecii pneumonia was a disease of the profoundly immunosuppressed, as with persons on cancer treatment or with profound malnutrition. KS in high-income countries was previously recognized as a disease of elderly men in the Mediterranean basin that was far more indolent than the form that was later associated with HIV infection (Di Lorenzo 2008). Both were previously unknown in apparently healthy young American men. A rush on the rarely used drug pentamidine for young men without coexisting cancer from the Centers for Disease Control and Prevention in 1981 was a sentinel event that alerted public health officials to the new
P. jirovecii outbreak (Selik et al. 1984). In quick succession, MSM with the same opportunistic infections (OIs) or malignancies (OMs) were reported from around the world.

From 1981 through the present (2011), MSM have remained the most afflicted group in high-income nations. For example, about half of all cases in the United States in 2009 are estimated to have occurred in MSM (El-Sadr et al. 2010). STD rates remain high for MSM in major U.S. cities, as documented for gonorrhea and chlamydia by the CDC STD Surveillance Network in 2009 (Fig. 2). Trends have been dramatically upward for gonorrhea in the CDC Gonococcal Isolate Surveillance Project from 1992 to 2009 (Fig. 3). Despite the worrisome trends among MSM as a whole, the proportion of all reported HIV/AIDS cases that have occurred among White MSM in the United States has dropped markedly from the $80+\%$ range in the early 1980 s to $25 \%$ in 2010 (Fig. 4). At the same time, the proportion of cases among Black MSM in the United States has risen from just a couple percent in the early 1980 s to about $24 \%$ in 2010 (El-Sadr et al. 2010). Both the prevalence and incidence rates for HIV/AIDS among Black MSM are now higher (Fig. 4) than any other subgroup of Americans, including IDUs. In Canada, Mexico, Western Europe, Australia, New Zealand, and higher-income island nations of the Caribbean, MSM continue to be the principal driver of the HIV/AIDS epidemic. This is also true of lower-income nations of Latin America and represents a growing proportion of cases in urban Asia (Baral et al. 2007; van Griensven and de Lind van Wijngaarden 2010).

The epidemic spread exceedingly among MSM, reaching peaks of greater than $50 \%$ prevalence of young MSM in the high-prevalence neighborhoods of three cities where it was first recognized (Los Angeles, New York, and San Francisco) by 1984. It is estimated that MSM incidence rates in the United States rose to $15 \%$ per annum in the early 1980 s in highprevalence communities. Rates rose among MSM in Western Europe, Australia, Canada, and other higher-income, non-Muslim countries, although not quite as quickly and gener- 

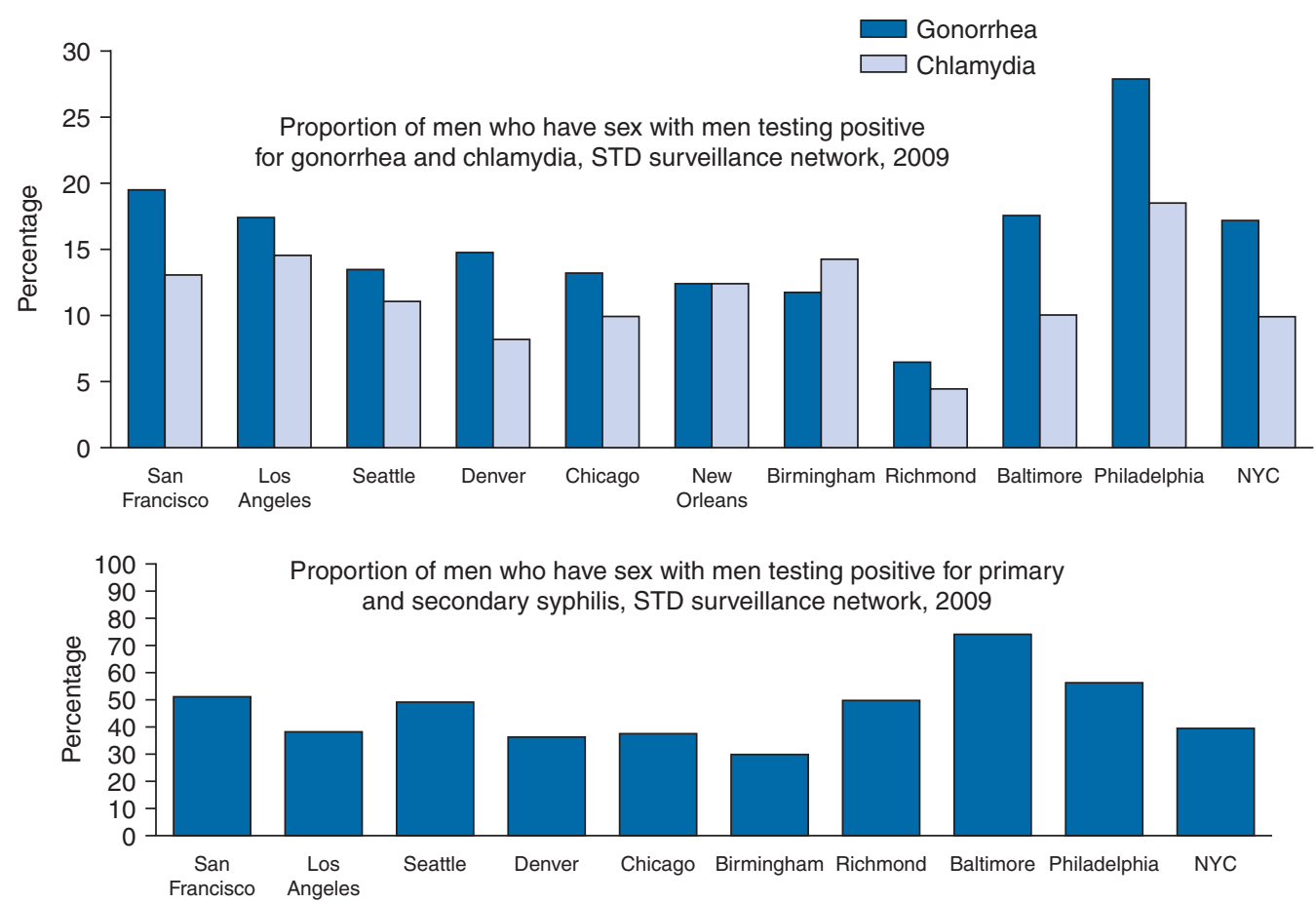

Figure 2. Proportion of men who have sex with men who had gonorrhea and chlamydia (top) and syphilis (bottom) in the STD (sexually transmitted disease) Surveillance Program of the Centers for Disease Control and Prevention (CDC), United States, 2009.

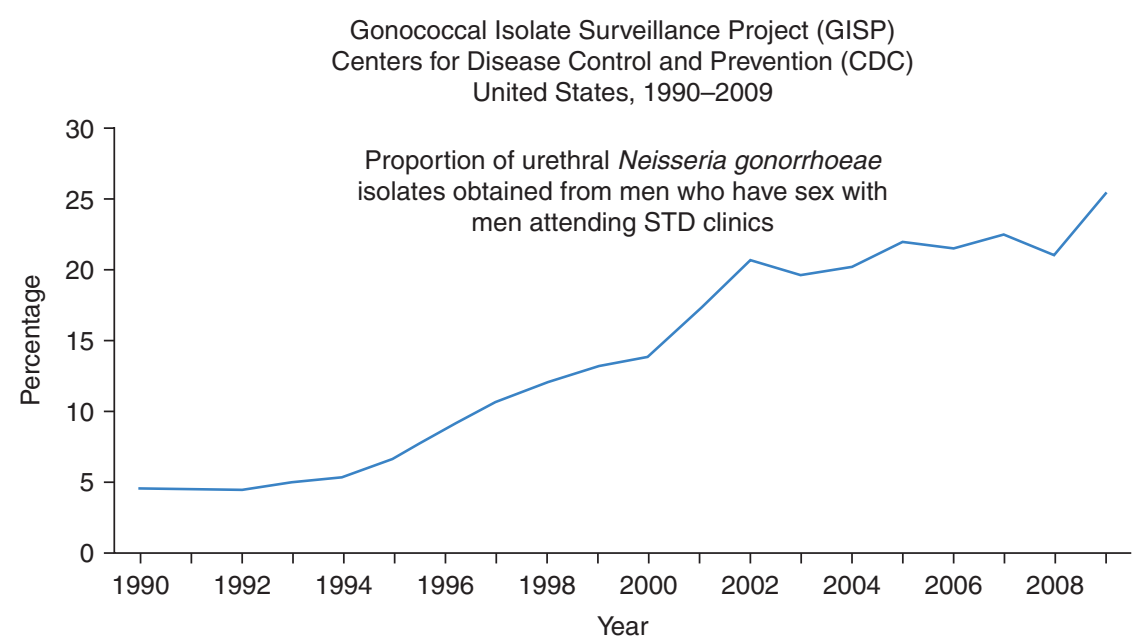

Figure 3. Proportion of urethral Neisseria gonorrhoeae isolates obtained from men who have sex with men attending sexually transmitted disease clinics from the Gonococcal Isolate Surveillance Project (GISP), Centers for Disease Control and Prevention (CDC), United States, 1990-2009. 
S.H. Vermund and A.J. Leigh-Brown
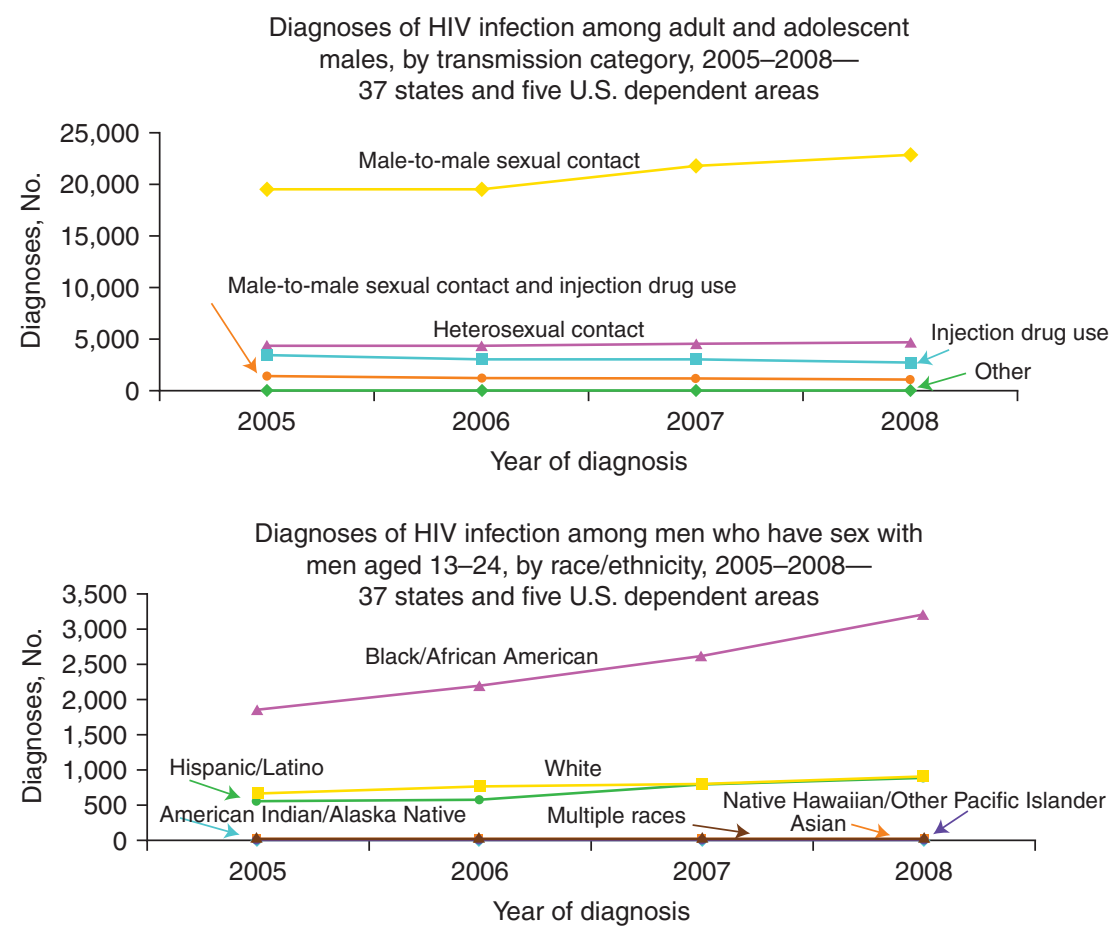

Figure 4. Diagnoses of HIV infection among adolescents and adult males by transmission category (top; all ages) and race/ethnicity (bottom; ages 13-24 years), Centers for Disease Control and Prevention (CDC), 37 states and five dependent areas of the United States, 2005-2008.

ally not as high as in the United States. In the mid-1980s, incidence rates declined in the Western world, likely due to both reduced risk behaviors and to a saturation effect of infection in the high-risk pool (i.e., the probability of becoming infected dropped owing to the uninfected persons not sexually mixing with infected, higher-risk persons). Evidence of reduced sexual risk taking by MSM in the late 1980s is found in declines in rectal gonorrhea and syphilis rates among MSM beginning in the mid-1980s. However, rates of STDs have rebounded among MSM, particularly among the young (Fig. 4). In 2009 surveillance, it is likely that such phenomena as "prevention fatigue," young MSM without a memory of AIDS in the pretreatment era, and minority MSM who are not reached by prevention messages targeting LGBTI communities (lesbian, gay, bisexual, transgender, intersex) are contributing to the worrisome trends in nations as diverse as the United States and China (Wolitski et al. 2001; Rietmeijer et al. 2003; Johnson et al. 2008; Scheer et al. 2008; Xu et al. 2010; Hao et al. 2011).

Both behavior and biology are relevant to the MSM epidemic. Multiple sexual partners, use of recreational drugs and alcohol proximate to sex, and the practice of unprotected anal intercourse all increase HIV risk markedly. Rectal exposure to HIV is more likely to infect than vaginal exposure (Powers et al. 2008; Boily et al. 2009; Baggaley et al. 2010). This is likely owing to the large surface area and thin epithelial layer of the rectum, its capacity for fluid absorption, trauma during anal sex, and the high numbers of immunological target cells in the gastrointestinal tract (Dandekar 2007; Brenchley and Douek 2008). Antiretroviral drugs taken orally by HIV-uninfected MSM as preexposure prophylaxis (PrEP) can protect against rectal infection from HIV, but only when these drugs 
are adhered to and systemic plasma levels are detectable (Grant et al. 2010). This was predicted by nonhuman primate challenge studies (Garcia-Lerma et al. 2008). It is not yet known whether topical PrEP in the form of rectal microbicides will be effective biologically and, if so, whether they will be used enough to make a difference in the epidemic (McGowan 2011). Circumcision is not likely to benefit MSM, as the principal risk derives from receptive anal intercourse (Millett et al. 2008; Vermund and Qian 2008).

\section{RISK EXPOSURES: INJECTION DRUG USE, NEEDLE SHARING, AND USE OF OTHER DRUGS/ALCOHOL}

Both illicit and licit drug and alcohol use are associated with HIV risk in several ways (Samet et al. 2007). Opioids like heroin and stimulants like cocaine and methamphetamines may be injected using needles and syringes that have been shared with other drug users. This sharing of injection "works" commonly shares blood from one user to another. This injection route is highly efficient in spreading HIV, as was seen in both North America and Western Europe (Booth et al. 2006, 2008). Needle/ syringe exchange programs (N/SEP) are effective at reducing HIV transmission among IDUs, but have been politically charged (Des Jarlais 2000; Downing et al. 2005; Shaw 2006; Tempalski et al. 2007). Some politicians and policymakers have argued that N/SEP should be banned because they will increase IDU use, although there is no evidence of this. Others have argued for the bans because they perceive $\mathrm{N} / \mathrm{SEP}$ as an inadequate response to a large need of comprehensive drug abuse prevention and treatment programs; support of N/SEP, they have argued, will discourage funding for the more comprehensive response.

Given the policy debates, it is not surprising that some countries were far more aggressive and successful in controlling the epidemic than others (Mathers et al. 2010). Australia is one model of IDU risk reduction efficiency. Making clean needles and syringes available widely, from any pharmacy as well as special services in neighborhoods with high drug use rates, is credited for maintaining IDU HIV prevalence $<2 \%$ for the past 30 years (Burrows 1998). In addition, the Australians have mainstreamed methadone use into the world of the general practitioner, reducing stigma and increasing access. Similarly, aggressive public health responses in Australia, Canada, and several Western European countries may have blunted the magnitude of HIV in their IDUs using N/SEP, and opioid substitution therapy. Even "medically supervised injecting centres" may have played a role, a topic of current study (Fischer et al. 2002).

Other nations were not as fortunate as Australia in having policies suitable to control the epidemic among IDUs (Lurie and Drucker 1997; Drucker et al. 1998). In the United States, for example, federal funding for N/SEP was banned by Congress until the early Obama administration (Millett et al. 2010), a ban with the active or the tacit approval of Reagan, G.H.W. Bush, Clinton, and G.W. Bush administrations. Funding for opioid substitution therapy did not meet the demand and waiting lists to join such programs were common. Doctors and venues licensed to distribute methadone are highly restricted, in direct contrast to the Australian approach. During that time, IDU incidence was high until community, local, and state initiatives introduced N/SEP programs that proved highly effective in reducing HIV incidence in American IDUs, as had been achieved by such programs earlier in Europe (Kwon et al. 2009; Jones et al. 2010; Palmateer et al. 2010).

Russia has had even worse policies and laws than the United States, banning opioid substitution therapy (both methadone and buprenorphine) altogether (as of 2011). Russia also has very limited N/SEP, and continues to experience some of the highest HIV seroconversion rates in the world among its IDUs (Aceijas et al. 2007; Sarang et al. 2008). The rest of Europe is a patchwork of both progressive and dysfunctional public policies vis-à-vis risk reduction for IDUs, depending in large part on whether the given nation is strongly connected to the European Community or whether 
they are more influenced by Russia. In summary, countries that have taken a more punitive, less pragmatic public health approach have been beleaguered by ongoing HIV spread among IDUs.

There has been a substantial increase in the 1980s and subsequent decrease of incidence and prevalence among IDUs in most high-income nations. Modeling suggests that the greater the volume of "dead space" in a used syringe, the higher the risk of residual blood infecting another drug user, as derived from ecological data on local IDU prevalence and local syringe usage patterns (Bobashev and Zule 2010). Evidence from the 1990s suggested that use of clean needles and syringes had dropped the likelihood of HIV transmission and acquisition substantially (Heimer 2008). The principal challenge is reaching all those IDUs who need N/SEP, drug treatment, and ancillary services, as well as to stem the tide of new users recruited among the young. Unfortunately, IDU itself seems to be expanding worldwide, partly owing to poor addiction and HIV care for many IDUs already infected (Wolfe et al. 2010).

Already highly endemic in Asia where most of the world's poppies are grown, the epidemic has been a principal driver of the epidemic in Iran, Pakistan, eastern India, China, Burma, Thailand, Cambodia, and Vietnam. In Africa, new reports of IDU in such unexpected venues as South Africa and Tanzania suggest the need for new research and action in that already HIVbeleaguered continent. Eastern Europe has seen some success in risk and incidence reduction, as in Estonia and Ukraine, but Russia continues to see robust HIV incidence among its IDUs owing to its failure to embrace opiate agonist therapy and vigorous N/SEP efforts (Sarang et al. 2007; Bobrova et al. 2008; Elovich and Drucker 2008; Krupitsky et al. 2010). That IDUs often cannot access clean needles and "works" when they need to in many countries of Eastern Europe and even in the United States, HIV continues to spread and cause preventable disease.

Non-IDU drug use and alcohol abuse were recognized early on as cofactors for high-risk sexual activity. "Poppers" are recreational stimulants that are popular among some MSM communities and used directly as a sexual enhancement. Disinhibition and failure to use condoms during sex have been associated particularly with stimulant and alcohol use (Khan et al. 2009; Parry et al. 2009; Hagan et al. 2011; Qian et al. 2011). There is also a body of literature citing the nonspecific immune activation resulting from drug use, from antigenic stimulation from contaminants, and immunosuppressive effects of alcohol use (Barve et al. 2002; Cabral 2006; Hahn and Samet 2010). Such immunostimulation could increase risk of acquisition of HIV by activated immune cells, whereas immunosuppression might further aggravate the $\mathrm{CD} 4^{+}$cell depletions caused by HIV. Prevention efforts to reduce HIV risk among noninjection drug and alcohol users have shown mixed results (Strauss and Rindskopf 2009; Strauss et al. 2009; Crawford and Vlahov 2010).

\section{RISK EXPOSURES: ADMINISTRATION OF BLOOD AND BLOOD PRODUCTS, AND IATROGENIC EXPOSURES}

Early in the epidemic, HIV-contaminated blood and blood products were a major contributor to the high incidence of infection in the Western world. The first cases reported in 1982 were men with hemophilia (Centers for Disease Control 1982; Evatt et al. 1985). Many nations began to screen for risk based on personally reported risk characteristics (such as MSM or IDU), but this was an imperfect way to tag the at-risk blood donations. A few countries added a surrogate for HIV risk, such as hepatitis B antigen or antibody, which improved the sensitivity of the screening in the pre-HIV test period before 1985 (Busch et al. 1997; Jackson et al. 2003). As concentrated factor VIII was a notable contributor to risk, heat-treated products were introduced, although for more than a year, the old products were still marketed, despite the known risk. When the first commercially available HIV antibody test was licensed in 1985, blood banking practices changed radically in most high-income nations. Sadly, politics interfered with policy in some settings (e.g., France) or 
economic consideration delayed screening, such that thousands of persons were still being infected, even in richer nations, where delays in introducing HIV screening resulted in transmissions. Today in 2011, many countries like the United States use both antibody screening and antigen screening using nucleic acid tests. This is to detect those persons who might be in the period between infection and seropositivity. Given the high viral load in these infected pre-seroconverters, risk of transmission is very high. Antibody testing of the blood supply is cost-effective, although antigen testing with PCR of seronegative blood products is not (AuBuchon et al. 1997). The new generation antibody-antigen dual serology tests will surely lead to reconsideration of PCR testing, as more persons infected with HIV in the window period will now be detected with serology.

Sharing needles and/or syringes is an exceedingly efficient way to transmit HIV, and this is not merely a phenomenon of IDU. It is also seen in dysfunctional health care settings such as orphanages in Romania, and hospitals in Libya (Hersh et al. 1991a; Rosenthal 2006). It remains a global disgrace that health care workers still reuse injection equipment in some settings; even national vaccine programs have been implicated when syringes/needles have run short owing to logistical supply chain problems or owing to graft (persons redirected syringes and needles for personal gain, but reusing needles/syringes for vaccine administration). Hence, WHO and other organizations have taken a strong interest in single-use syringes to avoid reuse of needles in the health care setting (Kane et al. 1999; Simonsen et al. 1999; Ekwueme et al. 2002; Sikora et al. 2010).

\section{RISK EXPOSURES: HETEROSEXUAL}

Heterosexual HIV spread has been a reality in the HIV epidemic from the very beginning of the recognition of the epidemic in high-income nations, although far less prevalent than in Africa. In the early days of statistics dominated by MSM, and then by IDUs, it was psychologically tempting to think that heterosexuals would be spared, although no other STD or blood-borne pathogen is transmitted only among MSM and not via male-female contact. In fact, the proportion of reported HIV/AIDS cases has risen steadily in high-income countries since the start of the epidemic in the West (Burchell et al. 2008; Kramer et al. 2008; Adimora et al. 2009; Mercer et al. 2009; Toussova et al. 2009). Although expanding more slowly than in Africa or among MSM, the large population at risk results in a substantial proportion of the persons infected with HIV attributable to heterosexual contact, one-fifth to one-third of the epidemic cases in non-IDUs in most highincome countries (Malebranche 2008; Rothenberg 2009; Mah and Halperin 2010).

The magnitude of the heterosexual epidemic in the northern hemisphere and higherincome nations has not reached anywhere near the magnitude seen in southern Africa. There are many possible explanations, all of them speculative and hard to demonstrate definitively. Viral infectiousness may be higher with the $\mathrm{C}$ clade of virus prevalence in southern Africa than with the B clade most common in the Americas, Europe, and Australia (Novitsky et al. 2010). A second speculation is that host genetics differ in Africans than in Caucasians such that African host susceptibility is higher (Pereyra et al. 2010). A third idea is that sexual partner mixing rates are higher in Africa where absentee worker husbands and intergenerational sex both drive risky behavior (KondeLule et al. 1997; Pickering et al. 1997; Yirrell et al. 1998; Gregson et al. 2002; Ekanem et al. 2005; Latora et al. 2006; Hallett et al. 2007; Helleringer and Kohler 2007; Katz and Low-Beer 2008; Doherty 2011; Fritz et al. 2011; Steffenson et al. 2011). A fourth explanation is that African tribal and ethnic groups that do not ritually circumcise their men are at especially high risk of high HIV transmission. There is little scientific consensus to date as to the relative importance of these and other factors.

Male circumcision is powerfully associated with reduced risk for HIV acquisition in both epidemiologic and experimental studies (Bongaarts et al. 1989; Weiss et al. 2000; Auvert et al. 2005; Bailey et al. 2007; Gray et al. 2007; Sahasrabuddhe and Vermund 2007; Mills et al. 
S.H. Vermund and A.J. Leigh-Brown

2008; Siegfried et al. 2009; Weiss et al. 2010). Protection was more than $50 \%$ in three independent clinical trials from South Africa, Kenya, and Uganda. Although American men are circumcised at high rates, European men are not, such that the dearth of a marked heterosexual epidemic in both North America and Europe suggests, at least, that circumcision status has not been a dominant factor in predicting heterosexual spread in the northern hemisphere.

\section{RISK EXPOSURES: MOTHER-TO-CHILD TRANSMISSION}

The steady increase of HIV among women in the West was the consequence of expanded transmission among MSM, some of whom were bisexual, and IDUs who were most often heterosexual and were sometimes women themselves. As the numbers of women with HIV infection rose, so too did the numbers of babies born who were exposed to HIV (Stringer and Vermund 1999). Fully one in four in North America and somewhat fewer (about one in eight) in Europe of exposed infants were infected in utero and intrapartum in the preART era (Stringer and Vermund 1999). Viral load of the mother correlated with transmission risk. Breastfeeding was avoided early on in the epidemic once it was apparent that breast milk of an HIV-infected nursing mother could infect her infant. Once zidovudine (and then nevirapine) was demonstrated to be safe and effective in the prevention of mother-to-child transmission (PMTCT), monotherapy was instituted with tremendous impact, reducing transmission to the infant by half or more (Lindegren et al. 1999; Mofenson and McIntyre 2000; Mofenson 2003).

Without intervention, about $5 \%$ of infected mothers will be expected to transmit HIV in utero to the fetus, about $20 \%$ will transmit intrapartum, and about 15\% will transmit through the breast milk, for an aggregate of $40 \%$ risk of infection to the infant (Mofenson and Fowler 1999). Prematurity increases this risk, as does high maternal viral load (VL), low maternal $\mathrm{CD}^{+}$cell count, and vaginal (vs. cesarean) delivery (Goldenberg et al. 2002; Fowler et al 2007). Discovery of a risk factor does not necessarily translate directly into a remediable action. For example, although bacterial vaginosis is a risk factor for preterm birth, and preterm birth is a risk factor for HIV infection from mother to child, use of antibiotics during pregnancy to reduce bacterial vaginosis did not reduce either prematurity or HIV infection in African women in a clinical trial (HPTN 024), beyond nevirapine (NVP) alone (Goldenberg et al. 2006a,b; Taha et al. 2006).

Problems with drug resistance were noted in PMTCT, as with ART therapy in general (Fogel et al. 2011a,b). Happily, most ART was demonstrated to be tolerable and safe in pregnancy (efavirenz is an exception), and combination ART (cART) is now the rule for HIVinfected pregnant women in high-income countries. Pediatric HIV has ceased to be a major public health problem in higher-income countries as routine "opt-out" testing for all pregnant women maximizes case detection, and use of cART reduces transmission to a minimum, with replacement "formula" feeding (Jamieson et al. 2007; Committee on Pediatric AIDS 2008; Gazzard et al. 2008). In Africa, in contrast, much progress is needed, although our tools for program evaluation and breastfeeding management have improved (Stringer et al. 2005, 2008, 2010; Reithinger et al. 2007; Mofenson 2010). The impact of opt-out testing in pregnancy, high coverage with cART, and replacement feeding for infants is encouraging in high-income nations. The peak of 1700 reported cases of pediatric AIDS occurred in 1992; subsequently, cases have decreased to $<50$ new cases of AIDS annually (a >96\% reduction) and $<300$ annual perinatal HIV transmissions in 2005; despite that, the number of HIV-infected women continues to rise (Fowler et al. 2010; Lansky et al. 2010). Given stability of HIV incidence and the frequency of pregnancy in HIV-infected women, the programs to prevent perinatal transmission must be maintained and access assured (Wade et al. 2004; Volmink et al. 2007; Peters et al. 2008; McDonald et al. 2009; Birkhead et al. 2010; Yang et al. 2010). 


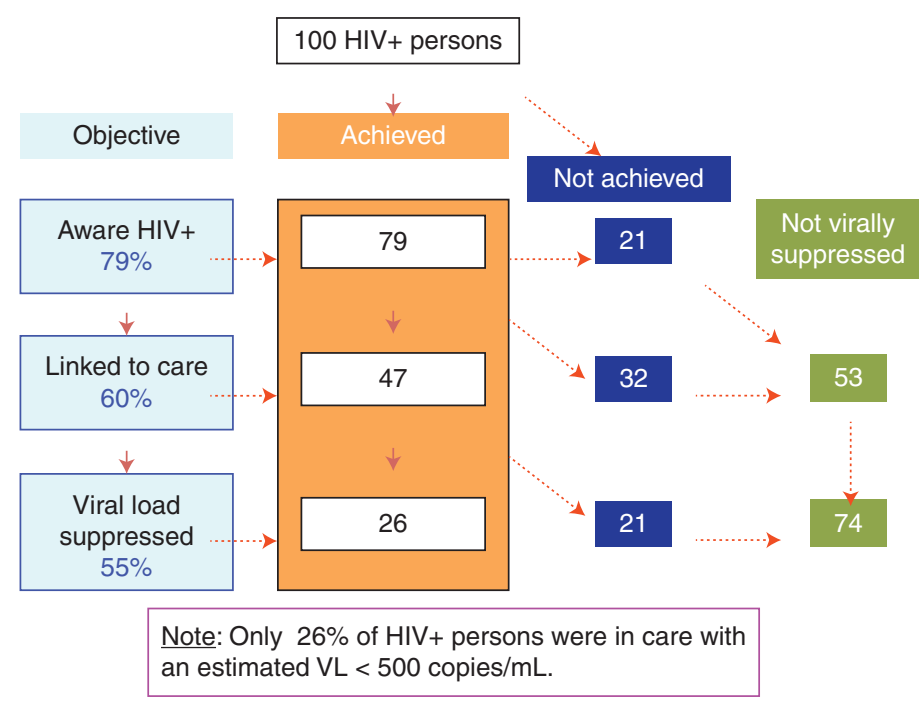

Figure 5. This is a model of how we estimate that only 26 of each $100 \mathrm{HIV}$-infected people in the United States are virally suppressed such that they would be expected to have a very slow disease progression and would be minimally infectious to others. Based on Centers for Disease Control and Prevention (CDC), United States, 2009 estimates of the proportion of HIV-infected persons in the United States who know their HIV-seropositive status (79\%), the proportion of those persons who are linked to HIV care $(60 \%)$, and the proportion of them who are virally suppressed (55\%), this is a cascade model of the overall number of $100 \mathrm{HIV}$-infected persons who are currently immunologically suppressed (only 26). (From Burns et al. 2010.)

\section{PREVENTION OF HIV IN HIGH- INCOME NATIONS}

Other works in this collection discuss preexposure prophylaxis and behavioral change, and we discussion prevention only very briefly here. Behavior change remains a backbone of interventions in higher-income nations, although results have been somewhat disappointing as with Project EXPLORE/HIVNET 015 (Chesney et al. 2003; Koblin et al. 2003, 2004; Colfax et al. 2004, 2005; Salomon et al. 2009). Combination interventions are now being explored (Barrow et al. 2008; Corsi and Booth 2008; Buchbinder 2009; Rotheram-Borus et al. 2009; Burns et al. 2010; Cohen et al. 2010; Crawford and Vlahov 2010; DeGruttola et al. 2010; El-Bassel et al. 2010; Read 2010; Reynolds and Quinn 2010), as are behavioral approaches with a better base in evidence (Collins et al. 2006; Harshbarger et al. 2006; Lyles et al. 2006; Wingood and DiClemente 2006; Margaret Dolcini et al. 2010). One strategy has been a conspicuous failure, namely "abstinence only" education, discovered to be associated with higher pregnancy rates than more comprehensive approaches that also highlighted STD prevention with condom use (Ott and Santelli 2007; Kohler et al. 2008; Trenholm et al. 2008). It is thought that the more pragmatic sexual education approaches in Europe and Australia, with structural changes like widespread provision of condom dispensing machines in bathrooms, may explain why the heterosexual epidemic among heterosexuals has been lower than in the United States where comprehensive sex education and condom advertising and distribution have been comparatively curtailed (Dworkin and Ehrhardt 2007). Structural interventions and behavior interventions can support biomedical advances in PrEP (both oral and topical [microbicides]), cART for prevention by reducing viral load among infectious persons (Fig. 5). Multicomponent interventions show promise and must be studied (Vermund et al. 2010; Kurth et al. 2011). 
S.H. Vermund and A.J. Leigh-Brown

\section{REFERENCES}

* Reference is also in this collection.

Abecasis AB, Lemey P, Vidal N, de Oliveira T, Peeters M, Camacho R, Shapiro B, Rambaut A, Vandamme AM. 2007. Recombination confounds the early evolutionary history of human immunodeficiency virus type 1: Subtype $\mathrm{G}$ is a circulating recombinant form. J Virol 81: 8543-8551.

Aceijas C, Stimson GV, Hickman M, Rhodes T. 2004. Global overview of injecting drug use and HIV infection among injecting drug users. AIDS 18: 2295-2303.

Aceijas C, Hickman M, Donoghoe MC, Burrows D, Stuikyte R. 2007. Access and coverage of needle and syringe programmes (NSP) in Central and Eastern Europe and Central Asia. Addiction 102: 1244-1250.

Adimora AA, Schoenbach VJ, Floris-Moore MA. 2009. Ending the epidemic of heterosexual HIV transmission among African Americans. Am J Prev Med 37: 468-471.

Alizon M, Wain-Hobson S, Montagnier L, Sonigo P. 1986. Genetic variability of the AIDS virus: Nucleotide sequence analysis of two isolates from African patients. Cell 46: 63-74.

Anderson JP, Rodrigo AG, Learn GH, Madan A, Delahunty C, Coon M, Girard M, Osmanov S, Hood L, Mullins JI. 2000. Testing the hypothesis of a recombinant origin of human immunodeficiency virus type 1 subtype E. J Virol 74: $10752-10765$.

Arnold C, Barlow KL, Parry JV, Clewley JP. 1995. At least five HIV-1 sequence subtypes (A, B, C, D, A/E) occur in England. AIDS Res Hum Retroviruses 11: 427-429.

AuBuchon JP, Birkmeyer JD, Busch MP. 1997. Costeffectiveness of expanded human immunodeficiency virus-testing protocols for donated blood. Transfusion 37: $45-51$.

Auvert B, Taljaard D, Lagarde E, Sobngwi-Tambekou J, Sitta R, Puren A. 2005. Randomized, controlled intervention trial of male circumcision for reduction of HIV infection risk: The ANRS 1265 trial. PLoS Med 2: e298. doi: 10.1371/journal.pmed.0020298.

Baggaley RF, White RG, Boily MC. 2010. HIV transmission risk through anal intercourse: Systematic review, metaanalysis and implications for HIV prevention. Int J Epidemiol 39: 1048-1063.

Bailey RC, Moses S, Parker CB, Agot K, Maclean I, Krieger JN, Williams CF, Campbell RT, Ndinya-Achola JO. 2007. Male circumcision for HIV prevention in young men in Kisumu, Kenya: A randomised controlled trial. Lancet 369: 643-656.

Balfe P, Simmonds P, Ludlam CA, Bishop JO, Brown AJ. 1990. Concurrent evolution of human immunodeficiency virus type 1 in patients infected from the same source: Rate of sequence change and low frequency of inactivating mutations. J Virol 64: 6221-6233.

Baral S, Sifakis F, Cleghorn F, Beyrer C. 2007. Elevated risk for HIV infection among men who have sex with men in low- and middle-income countries 2000-2006: A systematic review. PLoS Med 4: e339. doi: 10.1371/ journal.pmed.0040339.

Barrow RY, Berkel C, Brooks LC, Groseclose SL, Johnson DB, Valentine JA. 2008. Traditional sexually transmitted disease prevention and control strategies: Tailoring for African American communities. Sex Transm Dis 35: S30-S39.

Barth RE, Huijgen Q, Taljaard J, Hoepelman AI. 2010. Hepatitis B/C and HIV in sub-Saharan Africa: An association between highly prevalent infectious diseases. A systematic review and meta-analysis. Int $J$ Infect Dis 14: e1024-e1031.

Barve SS, Kelkar SV, Gobejishvilli L, Joshi-Barve S, McClain CJ. 2002. Mechanisms of alcohol-mediated $\mathrm{CD}^{+}{ }^{+} \mathrm{T}$ lymphocyte death: Relevance to HIV and HCV pathogenesis. Front Biosci 7: d1689-d1696.

Birkhead GS, Pulver WP, Warren BL, Hackel S, Rodriguez D, Smith L. 2010. Acquiring human immunodeficiency virus during pregnancy and mother-to-child transmission in New York: 2002-2006. Obstet Gynecol 115: 1247-1255.

Bobashev GV, Zule WA. Modeling the effect of high deadspace syringes on the human immunodeficiency virus (HIV) epidemic among injecting drug users. 2010. Addiction 105: 1439-1447.

Bobkov A, Cheingsong-Popov R, Garaev M, Rzhaninova A, Kaleebu P, Beddows S, Bachmann MH, Mullins JI, Louwagie J, Janssens W, et al. 1994. Identification of an env G subtype and heterogeneity of HIV-1 strains in the Russian Federation and Belarus. AIDS 8: 1649-1655.

Bobkov A, Cheingsong-Popov R, Selimova L, Ladnaya N, Kazennova E, Kravchenko A, Fedotov E, Saukhat S, Zverev S, Pokrovsky V, et al. 1997. An HIV type 1 epidemic among injecting drug users in the former Soviet Union caused by a homogeneous subtype A strain. AIDS Res Hum Retroviruses 13: 1195-1201.

Bobkov A, Kazennova E, Khanina T, Bobkova M, Selimova L, Kravchenko A, Pokrovsky V, Weber J. 2001. An HIV type 1 subtype A strain of low genetic diversity continues to spread among injecting drug users in Russia: Study of the new local outbreaks in Moscow and Irkutsk. AIDS Res Hum Retroviruses 17: 257-261.

Bobkov AF, Kazennova EV, Sukhanova AL, Bobkova MR, Pokrovsky VV, Zeman VV, Kovtunenko NG, Erasilova IB. 2004. An HIV type 1 subtype A outbreak among injecting drug users in Kazakhstan. AIDS Res Hum Retroviruses 20: 1134-1136.

Bobrova N, Rughnikov U, Neifeld E, Rhodes T, Alcorn R, Kirichenko S, Power R. 2008. Challenges in providing drug user treatment services in Russia: Providers' views. Subst Use Misuse 43: 1770-1784.

Boily MC, Baggaley RF, Wang L, Masse B, White RG, Hayes RJ, Alary M. 2009. Heterosexual risk of HIV-1 infection per sexual act: Systematic review and meta-analysis of observational studies. Lancet Infect Dis 9: 118-129.

Bongaarts J, Reining P, Way P, Conant F. 1989. The relationship between male circumcision and HIV infection in African populations. AIDS 3: 373-377.

Booth RE, Kwiatkowski CF, Brewster JT, Sinitsyna L, Dvoryak S. 2006. Predictors of HIV sero-status among drug injectors at three Ukraine sites. AIDS 20: 2217-2223.

Booth RE, Lehman WE, Kwiatkowski CF, Brewster JT, Sinitsyna L, Dvoryak S. 2008. Stimulant injectors in Ukraine: The next wave of the epidemic? AIDS Behav 12: 652-661. 
Brenchley JM, Douek DC. 2008. HIV infection and the gastrointestinal immune system. Mucosal Immunol 1: 23-30.

Brenner BG, Roger M, Moisi DD, Oliveira M, Hardy I, Turgel R, Charest H, Routy JP, Wainberg MA. 2008. Transmission networks of drug resistance acquired in primary/early stage HIV infection. AIDS 22: 2509-2515.

Buchbinder S. 2009. The epidemiology of new HIV infections and interventions to limit HIV transmission. Top HIV Med 17: 37-43.

Burchell AN, Calzavara LM, Orekhovsky V, Ladnaya NN. 2008. Characterization of an emerging heterosexual HIV epidemic in Russia. Sex Transm Dis 35: 807-813.

Burns DN, Dieffenbach CW, Vermund SH. 2010. Rethinking prevention of HIV type 1 infection. Clin Infect Dis 51: 725-731.

Burrows D. 1998. Injecting equipment provision in Australia: The state of play. Subst Use Misuse 33: 1113-1127.

Busch MP, Dodd RY, Lackritz EM, AuBuchon JP, Birkmeyer JD, Petersen LR. 1997. Value and cost-effectiveness of screening blood donors for antibody to hepatitis B core antigen as a way of detecting window-phase human immunodeficiency virus type 1 infections. The HIV Blood Donor Study Group. Transfusion 37: 1003-1011.

Cabral GA. 2006. Drugs of abuse, immune modulation, and AIDS. J Neuroimmune Pharmacol 1: 280-295.

Cane P, Chrystie I, Dunn D, Evans B, Geretti AM, Green H, Phillips A, Pillay D, Porter K, Pozniak A, et al. 2005. Time trends in primary resistance to HIV drugs in the United Kingdom: Multicentre observational study. BMJ 331: 1368.

* Carrington M, Alter G. 2011. Innate immune control of HIV disease. Cold Spring Harbor Perspect Med doi: 10.1101/cshperspect.a007070.

Centers for Disease Control. 1981. Kaposi's sarcoma and Pneumocystis pneumonia among homosexual menNew York City and California. MMWR Morb Mortal Wkly Rep 30: 305-308.

Centers for Disease Control. 1982. Update on acquired immune deficiency syndrome (AIDS)—United States. MMWR Morb Mortal Wkly Rep 31: 507-508, 513-504.

Chaix ML, Descamps D, Wirden M, Bocket L, Delaugerre C Tamalet C, Schneider V, Izopet J, Masquelier B, Rouzioux C, et al. 2009. Stable frequency of HIV-1 transmitted drug resistance in patients at the time of primary infection over 1996-2006 in France. AIDS 23: 717-724.

Chesney MA, Koblin BA, Barresi PJ, Husnik MJ, Celum CL, Colfax G, Mayer K, McKirnan D, Judson FN, Huang Y, et al. 2003. An individually tailored intervention for HIV prevention: Baseline data from the EXPLORE Study. Am J Public Health 93: 933-938.

Cohen MS, Gay CL, Busch MP, Hecht FM. 2010. The detection of acute HIV infection. J Infect Dis 202 Suppl 2: S270-S277.

Cohen MS, Haynes BF, McMichael AJ, Shaw GM. 2011. Medical Progress: Acute HIV-1 infection. N Engl J Med 364: 1943-1954.

Colfax G, Vittinghoff E, Husnik MJ, McKirnan D, Buchbinder S, Koblin B, Celum C, Chesney M, Huang Y, Mayer K, et al. 2004. Substance use and sexual risk: A participant- and episode-level analysis among a cohort
The HIV Epidemic: High-Income Countries

of men who have sex with men. Am J Epidemiol 159: 1002-1012.

Colfax G, Coates TJ, Husnik MJ, Huang Y, Buchbinder S, Koblin B, Chesney M, Vittinghoff E. 2005. Longitudinal patterns of methamphetamine, popper (amyl nitrite), and cocaine use and high-risk sexual behavior among a cohort of San Francisco men who have sex with men. J Urban Health 82: 62-70.

Collins C, Harshbarger C, Sawyer R, Hamdallah M. 2006. The diffusion of effective behavioral interventions project: Development, implementation, and lessons learned. AIDS Educ Prev 18: 5-20.

Committee on Pediatric AIDS. 2008. HIV testing and prophylaxis to prevent mother-to-child transmission in the United States. Pediatrics 122: 1127-1134.

Corsi KF, Booth RE. 2008. HIV sex risk behaviors among heterosexual methamphetamine users: Literature review from 2000 to present. Curr Drug Abuse Rev 1: 292-296.

Coutinho RA, van Griensven GJ, Moss A. 1989. Effects of preventive efforts among homosexual men. AIDS 3 Suppl 1: S53-S56.

Crandall KA, Vasco DA, Posada D, Imamichi H. 1999. Advances in understanding the evolution of HIV. AIDS 13 Suppl A: S39-S47.

Crawford ND, Vlahov D. 2010. Progress in HIV reduction and prevention among injection and noninjection drug users. J Acquir Immune Defic Syndr 55 Suppl 2: S84-S87.

Dandekar S. 2007. Pathogenesis of HIV in the gastrointestinal tract. Curr HIV/AIDS Rep 4: 10-15.

De Cock KM, Brun-Vezinet F. 1989. Epidemiology of HIV-2 infection. AIDS 3 Suppl 1: S89-S95.

DeGruttola V, Smith DM, Little SJ, Miller V. 2010. Developing and evaluating comprehensive HIV infection control strategies: Issues and challenges. Clin Infect Dis $\mathbf{5 0}$ Suppl 3: S102-S107.

Dehne KL, Khodakevich L, Hamers FF, Schwartlander B. 1999. The HIV/AIDS epidemic in eastern Europe: Recent patterns and trends and their implications for policymaking. AIDS 13: 741-749.

Des Jarlais DC. 2000. Research, politics, and needle exchange. Am J Public Health 90: 1392-1394.

de Oliveira T, Pillay D, Gifford RJ. 2010. The HIV-1 subtype $\mathrm{C}$ epidemic in South America is linked to the United Kingdom. PLoS One 5: e9311. doi: 10.1371/journal. pone.0009311.

de Ronde A, Schuurman R, Goudsmit J, van den Hoek A, Boucher C. 1996. First case of new infection with zidovudine-resistant HIV-1 among prospectively studied intravenous drug users and homosexual men in Amsterdam, The Netherlands. AIDS 10: 231-232.

Di Lorenzo G. 2008. Update on classic Kaposi sarcoma therapy: New look at an old disease. Crit Rev Oncol Hematol 68: 242-249.

Doherty IA. 2011. Sexual networks and sexually transmitted infections: Innovations and findings. Curr Opin Infect Dis 24: 70-77.

Downing M, Riess TH, Vernon K, Mulia N, Hollinquest M, McKnight C, Jarlais DC, Edlin BR. 2005. What's community got to do with it? Implementation models of syringe exchange programs. AIDS Educ Prev 17: 68-78. 
S.H. Vermund and A.J. Leigh-Brown

Drucker E, Lurie P, Wodak A, Alcabes P. 1998. Measuring harm reduction: The effects of needle and syringe exchange programs and methadone maintenance on the ecology of HIV. AIDS 12 Suppl A: S217-S230.

Drummond AJ, Rambaut A. 2007. BEAST: Bayesian evolutionary analysis by sampling trees. BMC Evol Biol 7: 214 .

Dworkin SL, Ehrhardt AA. 2007. Going beyond "ABC" to include "GEM": Critical reflections on progress in the HIV/AIDS epidemic. Am J Public Health 97: 13-18.

Dwyre DM, Fernando LP, Holland PV. 2011. Hepatitis B, hepatitis C and HIV transfusion-transmitted infections in the 21st century. Vox Sang 100: 92-98.

Ekanem EE, Afolabi BM, Nuga AO, Adebajo SB. 2005. Sexual behaviour, HIV-related knowledge and condom use by intra-city commercial bus drivers and motor park attendants in Lagos, Nigeria. Afr J Reprod Health 9: $78-87$.

Ekwueme DU, Weniger BG, Chen RT. 2002. Model-based estimates of risks of disease transmission and economic costs of seven injection devices in sub-Saharan Africa. Bull World Health Organ 80: 859-870.

El-Bassel N, Gilbert L, Witte S, Wu E, Hunt T, Remien RH. 2010. Couple-based HIV prevention in the United States: Advantages, gaps, and future directions. J Acquir Immune Defic Syndr 55 Suppl 2: S98-S101.

Elovich R, Drucker E. 2008. On drug treatment and social control: Russian narcology's great leap backwards. Harm Reduct J 5: 23.

El-Sadr WM, Mayer KH, Hodder SL. 2010. AIDS in America-Forgotten but not gone. $N$ Engl J Med 362: 967-970.

Evatt BL, Gomperts ED, McDougal JS, Ramsey RB. 1985. Coincidental appearance of LAV/HTLV-III antibodies in hemophiliacs and the onset of the AIDS epidemic. $N$ Engl J Med 312: 483-486.

Fischer B, Rehm J, Kirst M, Casas M, Hall W, Krausz M, Metrebian N, Reggers J, Uchtenhagen A, van den Brink W, et al. 2002. Heroin-assisted treatment as a response to the public health problem of opiate dependence. Eur J Public Health 12: 228-234.

Fogel J, Hoover DR, Sun J, Mofenson LM, Fowler MG, Taylor AW, Kumwenda N, Taha TE, Eshleman SH. 2011a. Analysis of nevirapine resistance in HIV-infected infants who received extended nevirapine or nevirapine/zidovudine prophylaxis. AIDS 25: 911-917.

Fogel J, Li Q, Taha TE, Hoover DR, Kumwenda NI, Mofenson LM, Kumwenda JJ, Fowler MG, Thigpen MC, Eshleman SH. 2011b. Initiation of antiretroviral treatment in women after delivery can induce multiclass drug resistance in breastfeeding HIV-infected infants. Clin Infect Dis 52: 1069-1076.

Fowler MG, Lampe MA, Jamieson DJ, Kourtis AP, Rogers MF. 2007. Reducing the risk of mother-to-child human immunodeficiency virus transmission: Past successes, current progress and challenges, and future directions. Am J Obstet Gynecol 197: S3-S9.

Fowler MG, Gable AR, Lampe MA, Etima M, Owor M. 2010. Perinatal HIV and its prevention: Progress toward an HIV-free generation. Clin Perinatol 37: 699-719, vii.

Fox J, Castro H, Kaye S, McClure M, Weber JN, Fidler S. 2010. Epidemiology of non-B clade forms of HIV-1 in men who have sex with men in the UK. AIDS 24: 2397-2401.

Fritz K, McFarland W, Wyrod R, Chasakara C, Makumbe K, Chirowodza A, Mashoko C, Kellogg T, Woelk G. 2011. Evaluation of a peer network-based sexual risk reduction intervention for men in beer halls in Zimbabwe: Results from a randomized controlled trial. AIDS Behav. doi: 10.1007/s10461-011-9922-1.

Frost SD, Nijhuis M, Schuurman R, Boucher CA, Brown AJ. 2000. Evolution of lamivudine resistance in human immunodeficiency virus type 1-infected individuals: The relative roles of drift and selection. $J$ Virol 74: $6262-6268$

Frost SD, Wrin T, Smith DM, Kosakovsky Pond SL, Liu Y, Paxinos E, Chappey C, Galovich J, Beauchaine J, Petropoulos CJ, et al. 2005. Neutralizing antibody responses drive the evolution of human immunodeficiency virus type 1 envelope during recent HIV infection. Proc Natl Acad Sci 102: 18514-18519.

Garcia-Lerma JG, Otten RA, Qari SH, Jackson E, Cong ME, Masciotra S, Luo W, Kim C, Adams DR, Monsour M et al. 2008. Prevention of rectal SHIV transmission in macaques by daily or intermittent prophylaxis with emtricitabine and tenofovir. PLoS Med 5: e28. doi: 10.1371/journal.pmed.0050028.

Gazzard B, Clumeck N, d'Arminio Monforte A, Lundgren JD. 2008. Indicator disease-guided testing for HIVThe next step for Europe? HIV Med 9 Suppl 2: 34-40.

Gilbert MT, Rambaut A, Wlasiuk G, Spira TJ, Pitchenik AE, Worobey M. 2007. The emergence of HIV/AIDS in the Americas and beyond. Proc Natl Acad Sci 104: $18566-$ 18570.

Goldenberg RL, Stringer JS, Sinkala M, Vermund SH. 2002. Perinatal HIV transmission: Developing country considerations. J Matern Fetal Neonatal Med 12: 149-158.

Goldenberg RL, Mudenda V, Read JS, Brown ER, Sinkala M, Kamiza S, Martinson F, Kaaya E, Hoffman I, Fawzi W, et al. 2006a. HPTN 024 study: Histologic chorioamnionitis, antibiotics and adverse infant outcomes in a predominantly HIV-1-infected African population. Am J Obstet Gynecol 195: 1065-1074.

Goldenberg RL, Mwatha A, Read JS, Adeniyi-Jones S, Sinkala M, Msmanga G, Martinson F, Hoffman I, Fawzi W, Valentine M, et al. 2006b. The HPTN 024 Study: The efficacy of antibiotics to prevent chorioamnionitis and preterm birth. Am J Obstet Gynecol 194: 650-661.

Gottlieb MS, Schroff R, Schanker HM, Weisman JD, Fan PT, Wolf RA, Saxon A. 1981. Pneumocystis carinii pneumonia and mucosal candidiasis in previously healthy homosexual men: Evidence of a new acquired cellular immunodeficiency. N Engl J Med 305: 1425-1431.

Grant RM, Lama JR, Anderson PL, McMahan V, Liu AY, Vargas L, Goicochea P, Casapia M, Guanira-Carranza JV, Ramirez-Cardich ME, et al. 2010. Preexposure chemoprophylaxis for HIV prevention in men who have sex with men. N Engl J Med 363: 2587-2599.

Gray RH, Kigozi G, Serwadda D, Makumbi F, Watya S, Nalugoda F, Kiwanuka N, Moulton LH, Chaudhary MA, Chen MZ, et al. 2007. Male circumcision for HIV prevention in men in Rakai, Uganda: A randomised trial. Lancet 369: 657-666. 
Gregson S, Nyamukapa CA, Garnett GP, Mason PR, Zhuwau T, Carael M, Chandiwana SK, Anderson RM. 2002. Sexual mixing patterns and sex-differentials in teenage exposure to HIV infection in rural Zimbabwe. Lancet 359: 1896-1903.

Hagan H, Perlman DC, Des Jarlais DC. 2011. Sexual risk and HIV infection among drug users in New York City: A pilot study. Subst Use Misuse 46: 201-207.

Hahn JA, Samet JH. 2010. Alcohol and HIV disease progression: Weighing the evidence. Curr HIV/AIDS Rep 7: 226-233.

Hallett TB, Gregson S, Lewis JJ, Lopman BA, Garnett GP 2007. Behaviour change in generalised HIV epidemics: impact of reducing cross-generational sex and delaying age at sexual debut. Sex Transm Infect 83 (Suppl 1): i50-i54.

Hamers FF, Batter V, Downs AM, Alix J, Cazein F, Brunet JB. 1997. The HIV epidemic associated with injecting drug use in Europe: Geographic and time trends. AIDS 11: 1365-1374.

Hao C, Yan H, Yang H, Huan X, Guan W, Xu X, Zhang M, Tang W, Wang N, Gu J, et al. 2011. The incidence of syphilis, HIV and HCV and associated factors in a cohort of men who have sex with men in Nanjing, China. Sex Transm Infect 87: 199-201.

Harshbarger C, Simmons G, Coelho H, Sloop K, Collins C. 2006. An empirical assessment of implementation, adaptation, and tailoring: The evaluation of CDC's National Diffusion of VOICES/VOCES. AIDS Educ Prev 18: 184-197.

Heimer R. 2008. Community coverage and HIV prevention Assessing metrics for estimating HIV incidence through syringe exchange. Int J Drug Policy 19 (Suppl 1): S65S73.

Helleringer S, Kohler HP. 2007. Sexual network structure and the spread of HIV in Africa: Evidence from Likoma Island, Malawi. AIDS 21: 2323-2332.

Hersh BS, Popovici F, Apetrei RC, Zolotusca L, Beldescu N, Calomfirescu A, Jezek Z, Oxtoby MJ, Gromyko A, Heymann DL. 1991a. Acquired immunodeficiency syndrome in Romania. Lancet 338: 645-649.

Hersh BS, Popovici F, Zolotusca L, Beldescu N, Oxtoby MJ, Gayle HD. 1991b. The epidemiology of HIV and AIDS in Romania. AIDS 5 (Suppl 2): S87-S92.

Holmes EC, Zhang LQ, Robertson P, Cleland A, Harvey E, Simmonds P, Leigh Brown AJ. 1995. The molecular epidemiology of human immunodeficiency virus type 1 in Edinburgh. J Infect Dis 171: 45-53.

Hue S, Pillay D, Clewley JP, Pybus OG. 2005. Genetic analysis reveals the complex structure of HIV-1 transmission within defined risk groups. Proc Natl Acad Sci 102: 4425-4429.

Hughes GJ, Fearnhill E, Dunn D, Lycett SJ, Rambaut A, Leigh Brown AJ. 2009. Molecular phylodynamics of the heterosexual HIV epidemic in the United Kingdom. PLoS Pathog 5: e1000590. doi: 10.1371/ journal.ppat.1000590.

Jackson BR, Busch MP, Stramer SL, AuBuchon JP. 2003. The cost-effectiveness of NAT for HIV, HCV, and HBV in whole-blood donations. Transfusion 43: 721-729.
Jamieson DJ, Clark J, Kourtis AP, Taylor AW, Lampe MA, Fowler MG, Mofenson LM. 2007. Recommendations for human immunodeficiency virus screening, prophylaxis, and treatment for pregnant women in the United States. Am J Obstet Gynecol 197: S26-S32.

Johnson CV, Mimiaga MJ, Bradford J. 2008. Health care issues among lesbian, gay, bisexual, transgender and intersex (LGBTI) populations in the United States: Introduction. J Homosex 54: 213-224.

Jones JH, Handcock MS. 2003. An assessment of preferential attachment as a mechanism for human sexual network formation. Proc Biol Sci 270: 1123-1128.

Jones L, Pickering L, Sumnall H, McVeigh J, Bellis MA. 2010. Optimal provision of needle and syringe programmes for injecting drug users: A systematic review. Int J Drug Policy 21: $335-342$.

Kalish ML, Robbins KE, Pieniazek D, Schaefer A, Nzilambi N, Quinn TC, St Louis ME, Youngpairoj AS, Phillips J, Jaffe HW, et al. 2004. Recombinant viruses and early global HIV-1 epidemic. Emerg Infect Dis 10: 1227-1234.

Kane A, Lloyd J, Zaffran M, Simonsen L, Kane M. 1999. Transmission of hepatitis B, hepatitis $\mathrm{C}$ and human immunodeficiency viruses through unsafe injections in the developing world: Model-based regional estimates. Bull World Health Organ 77: 801-807.

Katz I, Low-Beer D. 2008. Why has HIV stabilized in South Africa, yet not declined further? Age and sexual behavior patterns among youth. Sex Transm Dis 35: 837-842.

Keeling MJ, Eames KT. 2005. Networks and epidemic models. J R Soc Interface 2: 295-307.

Khan MR, Bolyard M, Sandoval M, Mateu-Gelabert P, Krauss B, Aral SO, Friedman SR. 2009. Social and behavioral correlates of sexually transmitted infection- and HIV-discordant sexual partnerships in Bushwick, Brooklyn, New York. J Acquir Immune Defic Syndr 51: 470-485.

Kilmarx PH. 2009. Global epidemiology of HIV. Curr Opin HIVAIDS 4: 240-246.

Koblin BA, Chesney MA, Husnik MJ, Bozeman S, Celum CL, Buchbinder S, Mayer K, McKirnan D, Judson FN, Huang Y, et al. 2003. High-risk behaviors among men who have sex with men in 6 US cities: Baseline data from the EXPLORE Study. Am J Public Health 93: 926-932.

Koblin B, Chesney M, Coates T. 2004. Effects of a behavioural intervention to reduce acquisition of HIV infection among men who have sex with men: The EXPLORE randomised controlled study. Lancet 364: $41-50$.

Kohler PK, Manhart LE, Lafferty WE. 2008. Abstinenceonly and comprehensive sex education and the initiation of sexual activity and teen pregnancy. J Adolesc Health 42: 344-351.

Konde-Lule JK, Sewankambo N, Morris M. 1997. Adolescent sexual networking and HIV transmission in rural Uganda. Health Transit Rev 7 (Suppl): 89-100.

Korber B, Muldoon M, Theiler J, Gao F, Gupta R, Lapedes A, Hahn BH, Wolinsky S, Bhattacharya T. 2000. Timing the ancestor of the HIV-1 pandemic strains. Science 288: $1789-1796$

Kouyos RD, von W, Yerly S, Boni J, Taffe P, Shah C, Burgisser P, Klimkait T, Weber R, Hirschel B, et al. 2010. Molecular 
S.H. Vermund and A.J. Leigh-Brown

epidemiology reveals long-term changes in HIV type 1 subtype B transmission in Switzerland. J Infect Dis 201: $1488-1497$.

Kramer MA, van Veen MG, de Coul EL, Geskus RB, Coutinho RA, van de Laar MJ, Prins M. 2008. Migrants travelling to their country of origin: A bridge population for HIV transmission? Sex Transm Infect 84: 554-555.

Krupitsky E, Woody GE, Zvartau E, O’Brien CP. 2010. Addiction treatment in Russia. Lancet 376: 1145.

Kuiken CL, Goudsmit J. 1994. Silent mutation pattern in V3 sequences distinguishes virus according to risk group in Europe. AIDS Res Hum Retroviruses 10: 319-320.

Kuiken CL, Cornelissen MT, Zorgdrager F, Hartman S, Gibbs AJ, Goudsmit J. 1996. Consistent risk groupassociated differences in human immunodeficiency virus type $1 \mathrm{vpr}$, vpu and $\mathrm{V} 3$ sequences despite independent evolution. J Gen Virol 77 (Pt 4): 783-792.

Kuiken C, Foley B, Leitner T, Apetrei RC, Hahn BH, Mizrachi I, Mullins JI, Rambaut A, Wolinsky S, Korber B, ed. 2010. HIV Sequence Compendium 2010. Theoretical Biology and Biophysics Group, Los Alamos National Laboratory, NM.

Kurth AE, Celum C, Baeten JM, Vermund SH, Wasserheit JN. 2011. Combination HIV prevention: Significance, challenges, and opportunities. Curr HIV/AIDS Rep 8: $62-72$.

Kwon JA, Iversen J, Maher L, Law MG, Wilson DP. 2009. The impact of needle and syringe programs on HIV and HCV transmissions in injecting drug users in Australia: A model-based analysis. J Acquir Immune Defic Syndr 51: 462-469.

* Lackner AA, Lederman MM, Rodriguez B. 2011. HIV pathogenesis-The host. Cold Spring Harb Perspect Med doi: 10.1101/cshperspect.a007005.

Lampe MA, Nesheim S, Shouse RL, Borkowf CB, Minasandram V, Little K, Kilmarx PH, Whitmore S, Taylor A, Valleroy L. 2010. Racial/ethnic disparities among children with diagnoses of perinatal HIV infection-34 states, 2004-2007. MMWR Morb Mortal Wkly Rep 59: 97-101.

Lansky A, Brooks JT, DiNenno E, Heffelfinger J, Hall HI, Mermin J. 2010. Epidemiology of HIV in the United States. J Acquir Immune Defic Syndr 55 Suppl 2: S64-S68.

Latora V, Nyamba A, Simpore J, Sylvette B, Diane S, Sylvere B, Musumeci S. 2006. Network of sexual contacts and sexually transmitted HIV infection in Burkina Faso. $J$ Med Virol 78: 724-729.

Leigh Brown AJ. 1997. Analysis of HIV-1 env gene sequences reveals evidence for a low effective number in the viral population. Proc Natl Acad Sci 94: 1862-1865.

Leigh Brown AJ, Richman DD. 1997. HIV-1: Gambling on the evolution of drug resistance? Nat Med 3: 268-271.

Leigh Brown AJ, Lobidel D, Wade CM, Rebus S, Phillips AN, Brettle RP, France AJ, Leen CS, McMenamin J, McMillan A, et al. 1997. The molecular epidemiology of human immunodeficiency virus type 1 in six cities in Britain and Ireland. Virology 235: 166-177.

Leigh Brown AJ, Frost SD, Mathews WC, Dawson K, Hellmann NS, Daar ES, Richman DD, Little SJ. 2003. Transmission fitness of drug-resistant human immunodeficiency virus and the prevalence of resistance in the antiretroviral-treated population. J Infect Dis 187: $683-686$.

Leigh Brown AJ, Lycett SJ, Weinert L, Hughes GJ, Fearnhill E, Dunn DT. UK HIV Drug Resistance Collaboration. 2011. Transmission network parameters estimated from HIV sequences for a nation-wide epidemic. J Infect Dis (in press).

Lemey P, Pybus OG, Wang B, Saksena NK, Salemi M, Vandamme AM. 2003. Tracing the origin and history of the HIV-2 epidemic. Proc Natl Acad Sci 100: 6588-6592.

Lewis F, Hughes GJ, Rambaut A, Pozniak A, Leigh Brown AJ. 2008. Episodic sexual transmission of HIV revealed by molecular phylodynamics. PLoS Med 5: e50. doi: 10.1371/journal.pmed.0050050.

Liitsola K, Tashkinova I, Laukkanen T, Korovina G, Smolskaja T, Momot O, Mashkilleyson N, Chaplinskas S, Brummer-Korvenkontio H, Vanhatalo J, et al. 1998. HIV-1 genetic subtype A/B recombinant strain causing an explosive epidemic in injecting drug users in Kaliningrad. AIDS 12: 1907-1919.

Liitsola K, Holm K, Bobkov A, Pokrovsky V, Smolskaya T, Leinikki P, Osmanov S, Salminen M. 2000. An AB recombinant and its parental HIV type 1 strains in the area of the former Soviet Union: Low requirements for sequence identity in recombination. UNAIDS Virus Isolation Network. AIDS Res Hum Retroviruses 16: 1047-1053.

Lindegren ML, Byers RHJr, Thomas P, Davis SF, Caldwell B, Rogers M, Gwinn M, Ward JW, Fleming PL. 1999. Trends in perinatal transmission of HIV/AIDS in the United States. JAMA 282: 531-538.

Little SJ, Daar ES, D’Aquila RT, Keiser PH, Connick E, Whitcomb JM, Hellmann NS, Petropoulos CJ, Sutton L, Pitt JA, et al. 1999. Reduced antiretroviral drug susceptibility among patients with primary HIV infection. JAMA 282: 1142-1149.

Little SJ, Holte S, Routy JP, Daar ES, Markowitz M, Collier AC, Koup RA, Mellors JW, Connick E, Conway B, et al. 2002. Antiretroviral-drug resistance among patients recently infected with HIV. N Engl J Med 347: 385-394.

Lukashov VV, Kuiken CL, Vlahov D, Coutinho RA, Goudsmit J. 1996. Evidence for HIV type 1 strains of U.S. intravenous drug users as founders of AIDS epidemic among intravenous drug users in northern Europe. AIDS Res Hum Retroviruses 12: 1179-1183.

Lurie P, Drucker E. 1997. An opportunity lost: HIV infections associated with lack of a national needle-exchange programme in the USA. Lancet 349: 604-608.

Lyles CM, Crepaz N, Herbst JH, Kay LS. 2006. Evidencebased HIV behavioral prevention from the perspective of the CDC's HIV/AIDS Prevention Research Synthesis Team. AIDS Educ Prev 18: 21-31.

Mah TL, Halperin DT. 2010. Concurrent sexual partnerships and the HIV epidemics in Africa: Evidence to move forward. AIDS Behav 14: 11-16; dicussion 34-17.

Mahajan AP, Sayles JN, Patel VA, Remien RH, Sawires SR, Ortiz DJ, Szekeres G, Coates TJ. 2008. Stigma in the HIV/AIDS epidemic: A review of the literature and recommendations for the way forward. AIDS 22 Suppl 2: S67-S79.

Mahy M, Warner-Smith M, Stanecki KA, Ghys PD. 2009. Measuring the impact of the global response to the 
AIDS epidemic: Challenges and future directions. $J$ Acquir Immune Defic Syndr 52 Suppl 2: S152-S159.

Malebranche DJ. 2008. Bisexually active Black men in the United States and HIV: Acknowledging more than the "down low". Arch Sex Behav 37: 810-816.

Margaret Dolcini M, Gandelman AA, Vogan SA, Kong C, Leak TN, King AJ, Desantis L, O'Leary A. 2010. Translating HIV interventions into practice: Community-based organizations' experiences with the diffusion of effective behavioral interventions (DEBIs). Soc Sci Med 71: 1839-1846.

Mathers BM, Degenhardt L, Ali H, Wiessing L, Hickman M, Mattick RP, Myers B, Ambekar A, Strathdee SA. 2010. HIV prevention, treatment, and care services for people who inject drugs: A systematic review of global, regional, and national coverage. Lancet 375: 1014-1028.

McDonald AM, Zurynski YA, Wand HC, Giles ML, Elliott EJ, Ziegler JB, Kaldor JM. 2009. Perinatal exposure to HIV among children born in Australia, 1982-2006. Med J Aust 190: 416-420.

McGowan I. 2011. Rectal microbicides: Can we make them and will people use them? AIDS Behav 15 (Suppl 1): S66-S71.

Mercer CH, Copas AJ, Sonnenberg P, Johnson AM, McManus S, Erens B, Cassell JA. 2009. Who has sex with whom? Characteristics of heterosexual partnerships reported in a national probability survey and implications for STI risk. Int J Epidemiol 38: 206-214.

Meyerhans A, Cheynier R, Albert J, Seth M, Kwok S, Sninsky J, Morfeldt-Manson L, Asjo B, Wain-Hobson S. 1989. Temporal fluctuations in HIV quasispecies in vivo are not reflected by sequential HIV isolations. Cell 58: 901-910.

Millett GA, Flores SA, Marks G, Reed JB, Herbst JH. 2008. Circumcision status and risk of HIV and sexually transmitted infections among men who have sex with men: A meta-analysis. JAMA 300: 1674-1684.

Millett GA, Crowley JS, Koh H, Valdiserri RO, Frieden T, Dieffenbach CW, Fenton KA, Benjamin R, Whitescarver J, Mermin J, et al. 2010. A way forward: The National HIV/AIDS Strategy and reducing HIV incidence in the United States. J Acquir Immune Defic Syndr 55 Suppl 2: S144-S147.

Mills E, Cooper C, Anema A, Guyatt G. 2008. Male circumcision for the prevention of heterosexually acquired HIV infection: A meta-analysis of randomized trials involving 11,050 men. HIV Med 9: 332-335.

Mofenson LM. 2003. Advances in the prevention of vertical transmission of human immunodeficiency virus. Semin Pediatr Infect Dis 14: 295-308.

Mofenson LM. 2010. Antiretroviral drugs to prevent breastfeeding HIV transmission. Antivir Ther 15: 537-553.

Mofenson LM, Fowler MG. 1999. Interruption of maternofetal transmission. AIDS 13 (Suppl A): S205-S214.

Mofenson LM, McIntyre JA. 2000. Advances and research directions in the prevention of mother-to-child HIV-1 transmission. Lancet 355: 2237-2244.

Novitsky V, Wang R, Bussmann H, Lockman S, Baum M, Shapiro R, Thior I, Wester C, Wester CW, Ogwu A, et al. 2010. HIV-1 subtype C-infected individuals maintaining high viral load as potential targets for the "test-and-treat" approach to reduce HIV transmission. PLoS One 5: e10148. doi: 10.1371/journal.pone.0010148.

Op de Coul EL, Prins M, Cornelissen M, van der Schoot A, Boufassa F, Brettle RP, Hernandez-Aguado L, Schiffer V, McMenamin J, Rezza G, et al. 2001. Using phylogenetic analysis to trace HIV-1 migration among western European injecting drug users seroconverting from 1984 to 1997. AIDS 15: 257-266.

Ott MA, Santelli JS. 2007. Abstinence and abstinence-only education. Curr Opin Obstet Gynecol 19: 446-452.

Ou CY, Takebe Y, Weniger BG, Luo CC, Kalish ML, Auwanit W, Yamazaki S, Gayle HD, Young NL, Schochetman G. 1993. Independent introduction of two major HIV-1 genotypes into distinct high-risk populations in Thailand. Lancet 341: 1171-1174.

* Overbaugh J, Morris L. 2011. The antibody response against HIV-1. Cold Spring Harbor Perspect Med doi: 10.1101/ cshperspect.a007039.

Palmateer N, Kimber J, Hickman M, Hutchinson S, Rhodes T, Goldberg D. 2010. Evidence for the effectiveness of sterile injecting equipment provision in preventing hepatitis $\mathrm{C}$ and human immunodeficiency virus transmission among injecting drug users: A review of reviews. Addiction 105: 844-859.

Pape J, Johnson WDJr. 1993. AIDS in Haiti 1982-1992. Clin Infect Dis 17 (Suppl 2): S341-S345.

Parry JV, Murphy G, Barlow KL, Lewis K, Rogers PA, Belda FJ, Nicoll A, McGarrigle C, Cliffe S, Mortimer PP, et al. 2001. National surveillance of HIV-1 subtypes for England and Wales: Design, methods, and initial findings. J Acquir Immune Defic Syndr 26: 381-388.

Parry CD, Carney T, Petersen P, Dewing S, Needle R. 2009. HIV-risk behavior among injecting or non-injecting drug users in Cape Town, Pretoria, and Durban, South Africa. Subst Use Misuse 44: 886-904.

Pereyra F, Jia X, McLaren PJ, Telenti A, de Bakker PI, Walker BD, Ripke S, Brumme CJ, Pulit SL, Carrington M, et al. 2010. The major genetic determinants of HIV-1 control affect HLA class I peptide presentation. Science 330: 1551-1557.

Perrin L, Yerly S, Rakik A, Kinloch S, Hirschel B. 1994. Transmission of 215 mutants in primary HIV infection and analysis after 6 months of zidovudine. AIDS 8: pS3.

Peters VB, Liu KL, Robinson LG, Dominguez KL, Abrams EJ, Gill BS, Thomas PA. 2008. Trends in perinatal HIV prevention in New York City, 1994-2003. Am J Public Health 98: 1857-1864.

Pickering H, Okongo M, Ojwiya A, Yirrell D, Whitworth J. 1997. Sexual networks in Uganda: Mixing patterns between a trading town, its rural hinterland and a nearby fishing village. Int J STD AIDS 8: 495-500.

Pinching AJ. 1984. The acquired immune deficiency syndrome. Clin Exp Immunol 56: 1-13.

Powers KA, Poole C, Pettifor AE, Cohen MS. 2008. Rethinking the heterosexual infectivity of HIV-1: A systematic review and meta-analysis. Lancet Infect Dis 8: 553-563.

Qian HZ, Stinnette SE, Rebeiro PF, Kipp AM, Shepherd BE, Samenow CP, Jenkins CA, No P, McGowan CC, Hulgan T, et al. 2011. The relationship between injection and noninjection drug use and HIV disease progression. J Subst Abuse Treat 41: 14-20. 
S.H. Vermund and A.J. Leigh-Brown

Quigg M, Rebus S, France AJ, McMenamin J, Darby G, Leigh Brown AJ. 1997. Mutations associated with zidovudine resistance in HIV-1 among recent seroconvertors. AIDS 11: 835-836.

Rambaut A, Robertson DL, Pybus OG, Peeters M, Holmes EC. 2001. Human immunodeficiency virus. Phylogeny and the origin of HIV-1. Nature 410: 1047-1048.

Rambaut A, Posada D, Crandall KA, Holmes EC. 2004. The causes and consequences of HIV evolution. Nat Rev Genet 5: 52-61.

Read JS. 2010. Prevention of mother-to-child transmission of HIV: Antiretroviral strategies. Clin Perinatol 37: 765-776, viii.

Reithinger R, Megazzini K, Durako SJ, Harris DR, Vermund SH. 2007. Monitoring and evaluation of programmes to prevent mother to child transmission of HIV in Africa. BMJ 334: 1143-1146.

Remien RH, Mellins CA. 2007. Long-term psychosocial challenges for people living with HIV: Let's not forget the individual in our global response to the pandemic. AIDS 21 (Suppl 5): S55-S63.

Resik S, Lemey P, Ping LH, Kouri V, Joanes J, Perez J, Vandamme AM, Swanstrom R. 2007. Limitations to contact tracing and phylogenetic analysis in establishing HIV type 1 transmission networks in Cuba. AIDS Res Hum Retroviruses 23: 347-356.

Reynolds SJ, Quinn TC. 2010. Setting the stage: Current state of affairs and major challenges. Clin Infect Dis $\mathbf{5 0}$ (Suppl 3): S71-S76.

Rietmeijer CA, Patnaik JL, Judson FN, Douglas JMJr. 2003. Increases in gonorrhea and sexual risk behaviors among men who have sex with men: A 12-year trend analysis at the Denver Metro Health Clinic. Sex Transm Dis 30: $562-567$.

Robbins KE, Lemey P, Pybus OG, Jaffe HW, Youngpairoj AS, Brown TM, Salemi M, Vandamme AM, Kalish ML. 2003. U.S. human immunodeficiency virus type 1 epidemic: Date of origin, population history, and characterization of early strains. J Virol 77: 6359-6366.

Robertson DL, Anderson JP, Bradac JA, Carr JK, Foley B, Funkhouser RK, Gao F, Hahn BH, Kalish ML, Kuiken C, et al. 2000. HIV-1 nomenclature proposal. Science 288: 55-56.

Rosenthal E. 2006. HIV injustice in Libya-Scapegoating foreign medical professionals. $N$ Engl J Med 355: 2505-2508.

Rothenberg R. 2009. HIV transmission networks. Curr Opin HIVAIDS 4: 260-265.

Rotheram-Borus MJ, Swendeman D, Chovnick G. 2009. The past, present, and future of HIV prevention: Integrating behavioral, biomedical, and structural intervention strategies for the next generation of HIV prevention. Annu Rev Clin Psychol 5: 143-167.

Sahasrabuddhe VV, Vermund SH. 2007. The future of HIV prevention: Control of sexually transmitted infections and circumcision interventions. Infect Dis Clin North Am 21: 241-257, xi.

Salemi M, de Oliveira T, Ciccozzi M, Rezza G, Goodenow MM. 2008. High-resolution molecular epidemiology and evolutionary history of HIV-1 subtypes in Albania. PLoS One 3: e1390. doi: 10.1371/journal.pone.0001390.
Salomon EA, Mimiaga MJ, Husnik MJ, Welles SL, Manseau MW, Montenegro AB, Safren SA, Koblin BA, Chesney MA, Mayer KH. 2009. Depressive symptoms, utilization of mental health care, substance use and sexual risk among young men who have sex with men in EXPLORE: Implications for age-specific interventions. AIDS Behav 13: $811-821$.

Sambrook J, Sleigh M, Engler JA, Broker TR. 1980. The evolution of the adenoviral genome. Ann NY Acad Sci 354: $426-452$.

Samet JH, Walley AY, Bridden C. 2007. Illicit drugs, alcohol, and addiction in human immunodeficiency virus. Panminerva Med 49: 67-77.

Sarang A, Stuikyte R, Bykov R. 2007. Implementation of harm reduction in Central and Eastern Europe and Central Asia. Int J Drug Policy 18: 129-135.

Sarang A, Rhodes T, Platt L. 2008. Access to syringes in three Russian cities: Implications for syringe distribution and coverage. Int J Drug Policy 19 (Suppl 1): S25-S36.

Scheer S, Kellogg T, Klausner JD, Schwarcz S, Colfax G, Bernstein K, Louie B, Dilley JW, Hecht J, Truong HM, et al. 2008. HIV is hyperendemic among men who have sex with men in San Francisco: 10-year trends in HIV incidence, HIV prevalence, sexually transmitted infections and sexual risk behaviour. Sex Transm Infect 84: 493-498.

Selik RM, Haverkos HW, Curran JW. 1984. Acquired immune deficiency syndrome (AIDS) trends in the United States, 1978-1982. Am J Med 76: 493-500.

* Sharp PM, Hahn BH. 2011. Origins of HIV and the AIDS pandemic. Cold Spring Harb Perspec Med doi: 10.1101/ cshperspect.a006841.

Shaw SJ. 2006. Public citizens, marginalized communities: The struggle for syringe exchange in Springfield, Massachusetts. Med Anthropol 25: 31-63.

* Shaw GM, Hunter E. 2011. HIV transmission. Cold Spring Harb Perspect Med doi: 10.1011/cshperspect.a006965.

Siegfried N, Muller M, Deeks JJ, Volmink J. 2009. Male circumcision for prevention of heterosexual acquisition of HIV in men. Cochrane Database Syst Rev CD003362.

Sikora C, Chandran AU, Joffe AM, Johnson D, Johnson M. 2010. Population risk of syringe reuse: Estimating the probability of transmitting bloodborne disease. Infect Control Hosp Epidemiol 31: 748-754.

Simon F, Loussert-Ajaka I, Damond F, Saragosti S, Barin F, Brun-Vezinet F. 1996. HIV type 1 diversity in northern Paris, France. AIDS Res Hum Retroviruses 12: 1427-1433.

Simonsen L, Kane A, Lloyd J, Zaffran M, Kane M. 1999. Unsafe injections in the developing world and transmission of bloodborne pathogens: A review. Bull World Health Organ 77: 789-800.

Steffenson AE, Pettifor AE, Seage GR 3rd, Rees HV, Cleary PD. 2011. Concurrent sexual partnerships and human immunodeficiency virus risk among South African youth. Sex Transm Dis. 38: 459-466.

Strauss SM, Rindskopf DM. 2009. Screening patients in busy hospital-based HIV care centers for hazardous and harmful drinking patterns: The identification of an optimal screening tool. J Int Assoc Physicians AIDS Care (Chic) 8: 347-353. 
Strauss SM, Tiburcio NJ, Munoz-Plaza C, Gwadz M, Lunievicz J, Osborne A, Padilla D, McCarty-Arias M, Norman R. 2009. HIV care providers' implementation of routine alcohol reduction support for their patients. AIDS Patient Care STDS 23: 211-218.

Stringer JS, Vermund SH. 1999. Prevention of mother-tochild transmission of HIV-1. Curr Opin Obstet Gynecol 11: $427-434$.

Stringer JS, Sinkala M, Maclean CC, Levy J, Kankasa C, Degroot A, Stringer EM, Acosta EP, Goldenberg RL, Vermund SH. 2005. Effectiveness of a city-wide program to prevent mother-to-child HIV transmission in Lusaka, Zambia. AIDS 19: 1309-1315.

Stringer EM, Chi BH, Chintu N, Creek TL, Ekouevi DK, Coetzee D, Tih P, Boulle A, Dabis F, Shaffer N, et al. 2008. Monitoring effectiveness of programmes to prevent mother-to-child HIV transmission in lower-income countries. Bull World Health Organ 86: 57-62.

Stringer EM, Ekouevi DK, Coetzee D, Tih PM, Creek TL, Stinson K, Giganti MJ, Welty TK, Chintu N, Chi BH, et al. 2010. Coverage of nevirapine-based services to prevent mother-to-child HIV transmission in 4 African countries. JAMA 304: 293-302.

* Swanstrom R, Coffin J. 2011. HIV-1 pathogenesis: The virus. Cold Spring Harb Perspect Biol. doi: 10.1101/ cshperspect.a007443.

Taha TE, Brown ER, Hoffman IF, Fawzi W, Read JS, Sinkala M, Martinson FE, Kafulafula G, Msamanga G, Emel L, et al. 2006. A phase III clinical trial of antibiotics to reduce chorioamnionitis-related perinatal HIV-1 transmission. AIDS 20: 1313-1321.

Tempalski B, Flom PL, Friedman SR, Des Jarlais DC, Friedman JJ, McKnight C, Friedman R. 2007. Social and political factors predicting the presence of syringe exchange programs in 96 US metropolitan areas. Am J Public Health 97: 437-447.

Thomson MM, Perez-Alvarez L, Najera R. 2002. Molecular epidemiology of HIV-1 genetic forms and its significance for vaccine development and therapy. Lancet Infect Dis 2: 461-471.

Toussova O, Shcherbakova I, Volkova G, Niccolai L, Heimer R, Kozlov A. 2009. Potential bridges of heterosexual HIV transmission from drug users to the general population in St. Petersburg, Russia: Is it easy to be a young female? J Urban Health 86 (Suppl 1): 121-130.

Trenholm C, Devaney B, Fortson K, Clark M, Bridgespan LQ, Wheeler J. 2008. Impacts of abstinence education on teen sexual activity, risk of pregnancy, and risk of sexually transmitted diseases. J Policy Anal Manage 27: 255-276.

van Griensven F, de Lind van Wijngaarden JW. 2010. A review of the epidemiology of HIV infection and prevention responses among MSM in Asia. AIDS 24: (Suppl 3): S30-S40.

Vercauteren J, Wensing AM, van de Vijver DA, Albert J, Balotta C, Hamouda O, Kucherer C, Struck D, Schmit JC, Asjo B, et al. 2009. Transmission of drug-resistant HIV-1 is stabilizing in Europe. I Infect Dis 200: 1503-1508.

Vermund SH, Allen KL, Karim QA. 2009. HIV-prevention science at a crossroads: Advances in reducing sexual risk. Curr Opin HIVAIDS 4: 266-273.
Vermund SH, Hodder SL, Justman JE, Koblin BA, Mastro TD, Mayer KH, Wheeler DP, El-Sadr WM. 2010. Addressing research priorities for prevention of HIV infection in the United States. Clin Infect Dis 50 Suppl 3: S149-155.

Vermund SH, Qian HZ. 2008. Circumcision and HIV prevention among men who have sex with men: No final word. JAMA 300: 1698-1700.

Volmink J, Siegfried NL, van der Merwe L, Brocklehurst P. 2007. Antiretrovirals for reducing the risk of motherto-child transmission of HIV infection. Cochrane Database Syst Rev CD003510.

Volz EM, Kosakovsky Pond SL, Ward MJ, Leigh Brown AJ, Frost SD. 2009. Phylodynamics of infectious disease epidemics. Genetics 183: 1421-1430.

Wade NA, Zielinski MA, Butsashvili M, McNutt LA, Warren BL, Glaros R, Cheku B, Pulver W, Pass K, Fox K, et al. 2004. Decline in perinatal HIV transmission in New York State (1997-2000). J Acquir Immune Defic Syndr 36: $1075-1082$.

* Walker B, McMichael A. 2011. The T-cell response to HIV. Cold Spring Harbor Perspect Med doi: 10.1101/ cshperspect.a007054.

Weinstock HS, Zaidi I, Heneine W, Bennett D, Garcia-Lerma JG, Douglas JMJr, LaLota M, Dickinson G, Schwarcz S, Torian L, et al. 2004. The epidemiology of antiretroviral drug resistance among drug-naive HIV-1-infected persons in 10 US cities. J Infect Dis 189: 2174-2180.

Weiss HA, Quigley MA, Hayes RJ. 2000. Male circumcision and risk of HIV infection in sub-Saharan Africa: A systematic review and meta-analysis. AIDS 14: 2361-2370.

Weiss HA, Dickson KE, Agot K, Hankins CA. 2010. Male circumcision for HIV prevention: Current research and programmatic issues. AIDS 24 (Suppl 4): S61-S69.

Wensing AM, van de Vijver DA, Angarano G, Asjo B, Balotta C, Boeri E, Camacho R, Chaix ML, Costagliola D, De Luca A, et al. 2005. Prevalence of drug-resistant HIV-1 variants in untreated individuals in Europe: Implications for clinical management. J Infect Dis 192: 958-966.

Whitmore SK, Patel-Larson A, Espinoza L, Ruffo NM, Rao S. 2010. Missed opportunities to prevent perinatal human immunodeficiency virus transmission in 15 jurisdictions in the United States during 2005-2008. Women Health 50: 414-425.

Whitmore SK, Zhang X, Taylor AW, Blair JM. 2011. Estimated number of infants born to HIV-infected women in the United States and five dependent areas, 2006. J Acquir Immune Defic Syndr. 57: 218-222.

* Williamson C, Shao Y. 2011. The HIV epidemic: Low- to middle-income countries. Cold Spring Harb Perspect Med doi: 10.1101/cshperspect.a007187.

Wingood GM, DiClemente RJ. 2006. Enhancing adoption of evidence-based HIV interventions: Promotion of a suite of HIV prevention interventions for African American women. AIDS Educ Prev 18: 161-170.

Wolfe D, Carrieri MP, Shepard D. 2010. Treatment and care for injecting drug users with HIV infection: A review of barriers and ways forward. Lancet 376: 355-366.

Wolfs TF, de Jong JJ, Van den Berg H, Tijnagel JM, Krone WJ, Goudsmit J. 1990. Evolution of sequences encoding the principal neutralization epitope of human 
S.H. Vermund and A.J. Leigh-Brown

immunodeficiency virus 1 is host dependent, rapid, and continuous. Proc Natl Acad Sci 87: 9938-9942.

Wolitski RJ, Valdiserri RO, Denning PH, Levine WC. 2001. Are we headed for a resurgence of the HIV epidemic among men who have sex with men? Am J Public Health 91: $883-888$.

Xu JJ, Zhang M, Brown K, Reilly K, Wang H, Hu Q, Ding H, Chu Z, Bice T, Shang H. 2010. Syphilis and HIV seroconversion among a 12-month prospective cohort of men who have sex with men in Shenyang, China. Sex Transm Dis 37: 432-439.

Yang Q, Boulos D, Yan P, Zhang F, Remis RS, Schanzer D, Archibald CP. 2010. Estimates of the number of prevalent and incident human immunodeficiency virus (HIV) infections in Canada, 2008. Can J Public Health 101: 486-490.
Yerly S, Junier T, Gayet-Ageron A, Amari EB, von Wyl V, Gunthard HF, Hirschel B, Zdobnov E, Kaiser L. 2009. The impact of transmission clusters on primary drug resistance in newly diagnosed HIV-1 infection. AIDS 23: $1415-1423$.

Yirrell DL, Pickering H, Palmarini G, Hamilton L, Rutemberwa A, Biryahwaho B, Whitworth J, Brown AJ. 1998. Molecular epidemiological analysis of HIV in sexual networks in Uganda. AIDS 12: 285-290.

Zetterberg V, Ustina V, Liitsola K, Zilmer K, Kalikova N, Sevastianova K, Brummer-Korvenkontio $\mathrm{H}$, Leinikki P, Salminen MO. 2004. Two viral strains and a possible novel recombinant are responsible for the explosive injecting drug use-associated HIV type 1 epidemic in Estonia. AIDS Res Hum Retroviruses 20: $1148-1156$. 


\section{$\&_{\mathrm{CSH}}^{\infty} \&$ Cold Spring Harbor

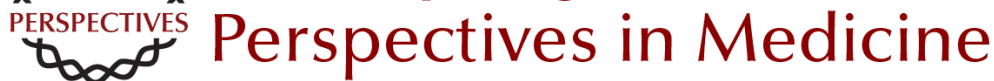

\section{The HIV Epidemic: High-Income Countries}

Sten H. Vermund and Andrew J. Leigh-Brown

Cold Spring Harb Perspect Med 2012; doi: 10.1101/cshperspect.a007195 originally published online February 15, 2012

\section{Subject Collection HIV}

HIV Pathogenesis: Dynamics and Genetics of

Viral Populations and Infected Cells John Coffin and Ronald Swanstrom

Human Immunodeficiency Virus Vaccine Trials Robert J. O'Connell, Jerome H. Kim, Lawrence Corey, et al.

HIV Transmission George M. Shaw and Eric Hunter

Novel Cell and Gene Therapies for HIV James A. Hoxie and Carl H. June

Behavioral and Biomedical Combination Strategies for HIV Prevention Linda-Gail Bekker, Chris Beyrer and Thomas C. Quinn

HIV-1 Assembly, Budding, and Maturation Wesley I. Sundquist and Hans-Georg Kräusslich

HIV-1 Assembly, Budding, and Maturation Wesley I. Sundquist and Hans-Georg Kräusslich

Lessons in Nonhuman Primate Models for AIDS Vaccine Research: From Minefields to Milestones Jeffrey D. Lifson and Nancy L. Haigwood
HIV-1 Pathogenesis: The Virus

Ronald Swanstrom and John Coffin

The T-Cell Response to HIV

Bruce Walker and Andrew McMichael

HIV-1 Reverse Transcription Wei-Shau Hu and Stephen H. Hughes

HIV Pathogenesis: The Host A.A. Lackner, Michael M. Lederman and Benigno Rodriguez

HIV: Cell Binding and Entry Craig B. Wilen, John C. Tilton and Robert W. Doms

Innate Immune Control of HIV Mary Carrington and Galit Alter

HIV DNA Integration

Robert Craigie and Frederic D. Bushman

HIV-1-Related Central Nervous System Disease: Current Issues in Pathogenesis, Diagnosis, and Treatment Serena Spudich and Francisco González-Scarano

For additional articles in this collection, see http://perspectivesinmedicine.cshlp.org/cgi/collection/ 